\title{
Characterization of Complexes Synthesized Using Schiff Base Ligands and Their Screening for Toxicity Two Fungal and One Bacterial Species on Rice Pathogens
}

\author{
T. Mangamamba, ${ }^{1}$ M. C. Ganorkar, ${ }^{1}$ and G. Swarnabala ${ }^{2,3}$ \\ ${ }^{1}$ Agarwal Siksha Samiti, Charminar, Hyderabad 500 002, India \\ ${ }^{2}$ Shadan PG Institute, Khairatabad, Hyderabad 500 001, India \\ ${ }^{3}$ Centre for Materials for Electronics Technology (C-MET), IDA Phase III, Cherlapally (HCL PO), Hyderabad 500 051, India \\ Correspondence should be addressed to G. Swarnabala; swarnabalaganti@gmail.com
}

Received 22 February 2014; Revised 8 May 2014; Accepted 9 May 2014; Published 18 September 2014

Academic Editor: Alfonso Castiñeiras

Copyright ( 2014 T. Mangamamba et al. This is an open access article distributed under the Creative Commons Attribution License, which permits unrestricted use, distribution, and reproduction in any medium, provided the original work is properly cited.

Coordination complexes with metal ions $\mathrm{Cu}(\mathrm{II}), \mathrm{Ni}(\mathrm{II}), \mathrm{Co}(\mathrm{II}), \mathrm{Fe}(\mathrm{III}), \mathrm{Mn}$ (II), $\mathrm{Cr}$ (III), and $\mathrm{VO}$ (II) with six ligands formed by condensation products using azides and aldehydes or ketones are characterized. Both the ligands and the complexes synthesized are characterized by $\mathrm{C}, \mathrm{H}, \mathrm{N}, \mathrm{Cl}$ and metal analyses, IR, UV-Vis, TGA, and magnetic susceptibility for tentative structure proposal. Several of them are screened for their toxicity (i.e., physiological activity) against fungal species Rhizoctonia solani and Acrocylindrium oryzae and a bacterium, Xanthomonas oryzae on rice pathogens. The study shows that the observed physiological activity is enhanced for the metal complexes as compared to the simple metal salts or ligands, except in the case of L3 or HAEP ligand, where the free $-\mathrm{OH}$ and $-\mathrm{NH}_{2}$ groups on the ligand seemed to have inhibited the activity. It is also observed that the order of activity has a dependence on the increased atomic weight of the metal ion in use. In some cases, especially the VO(II) complexes, they are found to be better than the standards in use, both for the fungicides and for the bactericide.

\section{Introduction}

Ever since the Italian chemist, Hugo Schiff used imines to make several "metallo-imines", numbers of variants of the condensation products of imines and aldehydes or ketones such as $\mathrm{RCH}=\mathrm{NR}^{\prime}$ - where $\mathrm{R} \& \mathrm{R}^{\prime}$ are alkyl and/or aryl substituent's, are popularized. They are also known as Schiff bases (SBs), anils, imines or azomethines. They are also known as anils, imines, or azomethines. These have several applications in organic studies, such as for building new heterocyclic systems, for identification, detection, and determination of aldehydes and ketones, for purification of carbonyl or amino compounds, or for the protection of these groups during the complex formation or such sensitive reactions [1]. They have other side applications in various other fields, coordination chemistry [2-9], analytical chemistry [10-16], pigments and dyes [17], and polymer industries [18], in vitamins and enzymes [4] for model biomolecules. There is a special mention of these complexes in agriculture [4] as fungicides, pesticides, and bacteriocides.

Survey of the literature for SB metal complexes and their applications showed excellent review articles $[19,20]$ for the detailed understanding of this class of compounds in all respects and one more especially dedicated to copper complexes [21]. They provide several details on number of metal complexes derived from SBs used widely for applications in food and dye industry, analytical chemistry, catalysis, polymers, antifertility, agrochemical, anti-inflammatory activity, antiradical activities, and biological systems as enzymatic agents. Several have reviewed them in light of their antimicrobial, antibacterial, antifungal, antitumor, and cytotoxic activities $[19,20]$. There are some individual articles too not mentioned in them with studies on the above mentioned types of activities with some metals ions such as $\mathrm{Cu}(\mathrm{II}), \mathrm{Ni}(\mathrm{II})$, and $\mathrm{Co}(\mathrm{II})$ with $\mathrm{SB}$ derived from salicylaldehyde and 2-substituted aniline [22]; 
$\mathrm{Cu}(\mathrm{II}), \mathrm{Ni}(\mathrm{II})$, and $\mathrm{Zn}(\mathrm{II})$ complexes with SB from p-chlorobenzaldehyde with p-chloroaniline [23]; $\mathrm{Mn}(\mathrm{II}), \mathrm{Fe}(\mathrm{II})$, $\mathrm{Ni}(\mathrm{II})$, and $\mathrm{Cu}(\mathrm{II})$ complexes with SB from 5-acetamido1,3,4-thiodiazole-2-sulphonamide and their biological activity [24]; $\mathrm{Zn}(\mathrm{II}), \mathrm{Ni}(\mathrm{II})$, and $\mathrm{Cu}(\mathrm{II})$ complexes with SB from dicinnamoylmethane and aromatic amines [25]; $\mathrm{Zn}(\mathrm{II}), \mathrm{Mn}(\mathrm{II}), \mathrm{Ni}(\mathrm{II})$, and $\mathrm{Cu}(\mathrm{II})$ complexes with $\mathrm{SB}$ from 2-hydroxy-1-naphthaldehyde and 5-amino-1-naphthol and their antibacterial activities [26]; $\mathrm{Co}(\mathrm{II}), \mathrm{Ni}(\mathrm{II})$, and $\mathrm{Cu}(\mathrm{II})$ complexes with SB from 1,4-dicarbonylphenyldihydrazide with 2,6-diformyl-4-methylphenol [27]; $\mathrm{Co}(\mathrm{II}), \mathrm{Ni}(\mathrm{II})$, and $\mathrm{Cu}(\mathrm{II})$ complexes with $\mathrm{SB}$ from $2-\mathrm{H} / \mathrm{Cl} / \mathrm{Br}-6-(4-$ fluorophenyliminomethyl)phenol [28]; $\mathrm{Co}(\mathrm{II}), \quad \mathrm{Ni}(\mathrm{II})$, and $\mathrm{Cu}(\mathrm{II})$ complexes with SB from pyrazolealdehyde with 2-aminophenol [29]; $\mathrm{Co}(\mathrm{II}), \mathrm{Ni}(\mathrm{II}), \mathrm{Zn}(\mathrm{II}), \mathrm{Cd}(\mathrm{II})$, $\mathrm{Hg}(\mathrm{II})$, and $\mathrm{Cu}(\mathrm{II})$ complexes with SB from benzofuran2-carbohydrazide and 4-methyl-thio-benzaldehyde and their antifungal, antibacterial activities being screened [30]; $\mathrm{Ni}(\mathrm{II})$ and $\mathrm{Cu}(\mathrm{II})$ complexes of SB derived from 1naphthylamine and 2-hydroxy-naphthalene-1-carbaldehyde [31]; $\mathrm{Fe}(\mathrm{III}), \mathrm{Ni}(\mathrm{II}), \mathrm{Cu}(\mathrm{II}), \mathrm{Co}(\mathrm{II}), \mathrm{Zn}(\mathrm{II})$, and $\mathrm{UO}_{2}$ (II) complexes of SB derived from 2-furancarboxaldehyde and ophenylenediamine [32]; $\mathrm{VO}(\mathrm{II}), \mathrm{Co}(\mathrm{II}), \mathrm{Rh}(\mathrm{III}), \mathrm{Pd}(\mathrm{II})$, and $\mathrm{Au}(\mathrm{III})$ complexes of $\mathrm{SB}$ derived from 4-nitrobenzoic acid and thiosemicarbazide and their antibacterial activity [33]; $\mathrm{VO}(\mathrm{IV}), \mathrm{Cu}(\mathrm{II})$, and $\mathrm{Ru}(\mathrm{II})$ complexes of SB derived from 3-hydroxyquinoxaline-2-carboxaldehyde and several amines 1,8-diaminonaphthalene, 2,3-diamine maleonitrile, 1,2-diaminocyclohexane, 2-iminophenol, and 4-aminoantipyrine [34]; $\mathrm{Mn}(\mathrm{II}), \mathrm{Co}(\mathrm{II}), \mathrm{Ni}(\mathrm{II}), \mathrm{Cu}(\mathrm{II})$, and $\mathrm{Zn}$ (II) complexes of SB derived from 1, 10-phenanthroline and o-vanillidene-2-aminobenzothiazole and o-vanillidene2-quino-N-(2-pyridyl)-benzenesulfonamide [35]; $\mathrm{Hg}$ (II), $\mathrm{Zn}(\mathrm{II})$, and $\mathrm{VO}(\mathrm{IV})$ complexes of SB from S-aminosulfonyl4-chloro-N-2,6-dimethylphenyl-2-hydroxybenzamide with salicylamide [36]; $\mathrm{Co}(\mathrm{II}), \mathrm{Cu}(\mathrm{II}), \mathrm{Ni}(\mathrm{II})$, and $\mathrm{Zn}(\mathrm{II})$ complexes of SB derived from several substituted pyridines with salicylaldehyde [37]. Recently new series of $\mathrm{Co}(\mathrm{II}), \mathrm{Ni}(\mathrm{II}), \mathrm{Cu}(\mathrm{II}), \mathrm{Cd}(\mathrm{II})$, and $\mathrm{Hg}$ (II) complexes were synthesized by the condensation of naphthofuran-2carbohydrazide and diacetylmonoxime. The ligand along with its metal complexes has been characterized on the basis of analytical data, IR, electronic, mass, ${ }^{1} \mathrm{HNMR}$, ESR spectral data, thermal studies, magnetic susceptibility, and molar conductance measurements. In order to evaluate the effect of metal ions upon chelation, both the ligand and its metal complexes were screened for their antibacterial and antifungal activities by minimum inhibitory concentration (MIC) method [38]. Metal chelates, $\left[\mathrm{M}(\mathrm{HL})_{2}\left(\mathrm{H}_{2} \mathrm{O}\right)_{2}\right] \mathrm{X}_{2}$ (where $\mathrm{M}=\mathrm{Mn}(\mathrm{II}), \mathrm{Co}(\mathrm{II}), \mathrm{Cu}(\mathrm{II}), \mathrm{Ni}(\mathrm{II})$, or $\mathrm{Zn}(\mathrm{II}), \mathrm{X}=$ $\mathrm{NO}_{3}{ }^{-}$or $\mathrm{Cl}-$, and $\mathrm{HL}=\mathrm{SB}$ moiety), have been prepared and characterized by elemental analysis, magnetic and spectroscopic measurements (infrared, X-ray powder diffraction, and scanning electron microscopy). The SB and its metal chelates have been screened for their in vitro antibacterial activity against four bacteria, gram-positive (Staphylococcus aureus) and gram-negative (Escherichia coli), and two strains of fungus (Aspergillus flavus and Candida albicans). The metal chelates were shown to possess more antibacterial activity than the free SB chelate [39].

Metal complexes of SBs derived from 2-furancarboxaldehyde and o-phenylenediamine (L1), and 2-thiophenecarboxaldehyde and 2-aminothiophenol (HL2) are reported and characterized based on elemental analyses, IR $1 \mathrm{H}$ NMR, solid reflectance, magnetic moment, molar conductance, and thermal analysis (TGA). Consider $\mathrm{M}=\mathrm{Fe}(\mathrm{III}), \mathrm{Ni}(\mathrm{II}), \mathrm{Cu}(\mathrm{II})$, $\mathrm{Co}(\mathrm{II}), \mathrm{Zn}(\mathrm{II})$, and UO2(II). The synthesized ligands, in comparison to their metal complexes, were also screened for their antibacterial activity against bacterial species, Escherichia coli, Pseudomonas aeruginosa, and Staphylococcus Pyogenes, as well as fungi (Candida). The activity data show the metal complexes to be more potent antibacterials than the parent SB ligand against one or more bacterial species [32].

Synthesis and characterisation of new transition metal complexes of SBs derived from 3-hydroxyquinoxaline-2carboxaldehyde and application of some of these complexes as hydrogenation and oxidation catalysts. The subnormal magnetic moment values substantiate a binuclear structure for all the $\mathrm{Cu}$ (II) complexes favouring square-planar geometry and those with magnetic moment of $1.76 \mathrm{BM}$ favoured octahedral geometry with mononuclear complex formation with this SB ligand [34].

It is found that the SBs selected for synthesis for this study have not been found in the literature. It is also noticed that many of the tridentate ligands are found to show striking biochemical characters where the azomethine linkage are blended into stable structured inorganic metal chelates. In a delicately balanced living system, physiological activity is a result of several chemical and physical processes. In such processes, the metal complexes furnished useful drugs and other substances as described by selective toxicity in pharmacology [40-42]. They function by upsetting this delicate balance in two ways: (a) by reinforcing the toxicity of a heavy metal and/or (b) by withdrawing the essential metal content from the system. For example, in highly basic iron rich soils, the metal ion, not available to the rootlets of plants, is extracted by spraying Ethylenediaminetetraacetic acid-(edta) in the form of a soluble complex. Such a mechanism for many fungicides and bactericides is described as a partition effect or cooperative effect [43]. Thus, to evaluate the chemical substances as fungicides and bactericides, the following methods are used commonly: (1) slide germination method [44-46], (2) test-tube dilution method [47], (3) cell-volume assay method [48], (4) inhibition-zone or modified paper disc method [49-51], and (5) poisoned food technique [50].

Three important rice pathogens were selected for the present study: two fungal species and a bacterium. The reasons for selecting these species are given in brief. (1) Rhizoctonia solani causes sheath blight $[52,53]$ which is a serious disease of the rice-crop. The symptoms are (a) grayish white patches and (b) yellowing of leaves. This spreads very quickly and causes enormous loss. It also causes several other diseases on many economically important commercial crops. (2) Acrocylindrium oryzae causes sheath rot of paddy decaying the sheath and was first reported [54-56] in India. A large number of fungicides are evaluated against this organism, in vitro and in vivo. A few of them are in use to 
arrest the disease yet it is quite uncontrolled. (3) Xanthomonas oryzae causes bacterial-leaf-blight and is usually noticed [54$56]$ in the field at the heading stage. The young seedlings, after transplanting, are affected when the upper leaves are rolled along the mid-rib to wither away. Subsequently, the disease extends to the whole field giving a burnt appearance. Applications of heavy doses of nitrogenous fertilizers are said to be the cause of this disease.

In this paper we report the synthesis of new SBs and their metal complexes. They were characterized by $\mathrm{C}, \mathrm{H}$, $\mathrm{N}, \mathrm{Cl}$ and metal analyses, Infra-red (IR), UV-Visible (UVVis), thermogravimetric analysis (TGA) for estimating coordinated water, and magnetic susceptibility measurements. By using the appropriate techniques or methods, these were screened for their toxicity against the chosen fungal and bacterial organisms. The results are summarized in the light of their observed physiological activity and a scope for future development.

\section{Materials and Methods}

2.1. Solvents and Reagents. Solvents were purified and distilled as per standard procedures [57]. Benzoic acid hydrazide or benzohydrazide [58,59], 2-hydroxybenzohydrazide or salicylhydrazide $[60,61]$, and 1-(2,4-dihydroxyphenyl)ethanone or resacetophenone [62] were prepared as per reported procedures. Hydrazine carbothioamide or thiosemicarbazide was recrystallized from water. The sodium salt of dehydroacetic acid or 3-acetyl-2-hydroxy-6-methyl-4H-pyran-4-one [63] was used as a white solid after treating with dil $\mathrm{HCl}$.

\subsection{SBs Ligands Synthesized Are the Following (Scheme 1)}

(1) BHFH or Ligand $1(\mathrm{~L} 1)=\mathrm{N}^{\prime}-\{\{$ furan-2-yl) methylene)-2-hydroxybenzohydrazide was obtained by condensing salicylhydrazide or 2-hydroxybenzohydrazide and furfuraldehyde or furan-2-carbaldehyde.

(2) BHEH or Ligand 2 (L2) = 2-hydroxy- $\mathrm{N}^{\prime}-(1-(2,4-$ dihydroxyphenyl)ethylidene) benzohydrazide) was obtained from salicylhydrazide or 2-hydroxybenzohydrazide and resacetophenone or 1-(2,4-dihydroxyphenyl)ethanone.

(3) HAEP or Ligand 3 (L3) = 1-(1-(2, 4-dihydroxyphenyl) ethylidene thiosemicarbazide was obtained from hydrazinecarbothioamide or thiosemicarbazide and resacetophenone or 1-(2, 4-dihydroxy phenyl)ethanone.

(4) $\mathrm{BFH}$ or Ligand 4 (L4) $=\mathrm{N}^{\prime}$-((furan-2-yl) methylene)benzohydrazide was obtained from benzohydrazide and furfuraldehyde or furan-2-carbaldehyde.

(5) $\mathrm{BHDH}$ or Ligand 5 (L5) = 2-hydroxyl- $\mathrm{N}^{\prime}-(1-(2-$ hydroxy-6-methyl-4-oxo-4H-pyran-3-yl)ethylidene) benzohydrazide was obtained from salicylhydrazide or 2-hydroxybenzohydrazide and dehydroacetic acid or 3-acetyl-2-hydroxy-6-methyl-4H-pyran-4-one.

(6) DHA or Ligand 6 (L6) = 3-acetyl-2-hydroxy-6-methyl-4H-pyran-4-one or dehydroacetic acid was used as it is.
2.3. Physical Measurements. C, H, and $\mathrm{N}$ analyses were done on Perkin-Elmer 240C analyzer. IR spectra were recorded on Perkin-Elmer grating spectrophotometer 577, near IR-VisUV spectra were recorded on DMR-21 in absorbance range of 300-2000 nm. Magnetic susceptibilities were determined at RT on Faraday's balance. The metal and chloride were estimated by gravimetry [64]. The TGA were analyzed in static air, using limiting temperature of $500^{\circ} \mathrm{C}$ and heating rate of $10^{\circ} \mathrm{C} / \mathrm{min}$.

2.4. Preparation of the Complexes. All the complexes were prepared by a very similar procedure: to the metal chloride (except VO(II) being a sulfate) in methanol, respective ligand dissolved in methanol is added slowly while stirring. This mixture was either refluxed for $30 \mathrm{~min}$ to $3 \mathrm{hrs}$ or digested for 1-2 h for different complexes [52]. Some complexes were obtained at $\mathrm{pH} 5.5$ and some around 8.5 depending on the basicity of the ligand in use. Quantitative precipitates were collected, washed, and dried.

The relevant physical data such as $\mathrm{C}, \mathrm{H}, \mathrm{N}, \mathrm{Cl}$, melting points or decomposition temperatures, colour, and metal analyses are compiled for each ligand and its complexes in Tables 1, 2, 3, 4, 5, and 6. For easy comparison and prediction of the complex formation with clarity on the denticity of the ligand, interpretation of the IR data of each ligand and its complexes are presented separately in Tables 7-12 with all the relevant explanation and references. The analysis of the magnetic susceptibility measurements, the bands obtained using the UV-Vis spectra, their transitions, the predicted geometries, and the interpreted molecular structures are discussed separately, for convenience, in Tables 13-19 for each metal ion forming complex with different ligands.

2.5. Physiological Activity. For the fungal species liquid broth method [52] was followed: peeled and cooked potato ( $350 \mathrm{~g})$ was collected into which dextrose $(35 \mathrm{~g})$ was dissolved and made up to $1750 \mathrm{~mL}$ by distilled water (PDA medium). $\mathrm{pH}$ was adjusted to 7.0 by adding drops of $\mathrm{NaOH}$ solution. It was distributed as $100 \mathrm{~mL}$ each into seventeen $250 \mathrm{~mL}$ conical flasks containing $2 \mathrm{~g}$ of agar-agar and $100 \mathrm{mg}$ metal complex for the organism Rhizoctonia solani. For the Acrocylindrium oryzae, it was distributed as $25 \mathrm{~mL}$ each into $70(150 \mathrm{~mL})$ conical flasks containing $25 \mathrm{mg}$ of the metal complex (1000 ppm).

All the flasks were tightly plugged with cotton and paper. They were all sterilized in the autoclave at $15 \mathrm{lbs}$ pressure and $121^{\circ} \mathrm{C}$ for $20 \mathrm{~min}$. The sterilized molten PDA medium from each flask, with the metal complex suspended uniformly, was poured into five petri dishes $(90 \mathrm{~mm}$ diameter and $20 \mathrm{~mL}$ each) and all the replicates were numbered and labeled immediately. All these specimens were inoculated and incubated along with a standard fungicide, Dithane M-45, for comparison. Control flasks without chemical were also inoculated and incubated simultaneously.

In the case of the bacterium well-zone or inhibitionzone technique $[49,51]$ was adopted. To hot $1 \mathrm{~L}$ distilled water, Hayward's medium [49-52] was added while stirring. The solution was made up to $2 \mathrm{~L}$ and $\mathrm{pH}$ adjusted to 7.0 by adding drops of $\mathrm{NaOH}$ solution. It was distributed equally 
L1<smiles>NNC(=O)c1ccccc1O</smiles>

2-Hydroxybenzohydrazide<smiles>O=Cc1ccco1</smiles>

Furan-2-carbaldehyde<smiles>O=C(N/N=C/c1ccco1)c1ccccc1O</smiles>

$N^{\prime}$-((Furan-2-yl)methylene)-2-hydroxybenzohydrazide
L2

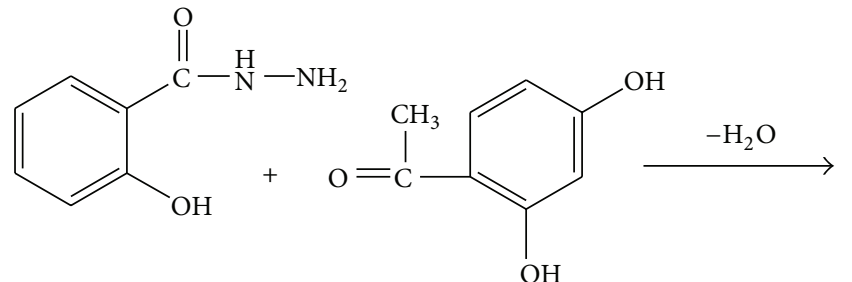

2-Hydroxybenzohydrazide<smiles>C/C(=N\NC(=O)c1ccccc1O)c1ccc(O)cc1O</smiles>

2-Hydroxy- $N^{\prime}-(1-(2,4-$ dihydroxyphenyl)ethylidene)benzohydrazide
L3

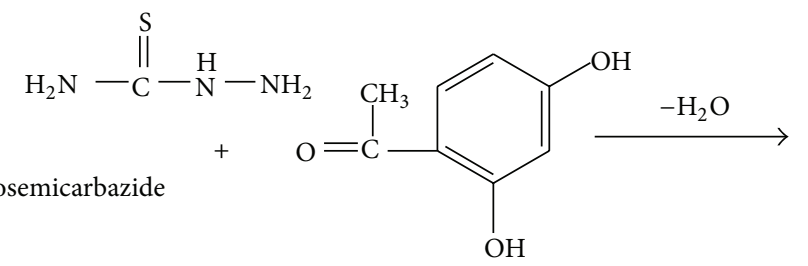

1-(2,4-dihydroxyphenyl)ethanone<smiles>C/C(=N\NC(N)=S)c1ccc(O)cc1O</smiles>

1-(1- $(2,4-$

dihydroxyphenyl)ethylidene)thiosemicarbazide
L4<smiles>NNC(=O)c1ccccc1</smiles>
Benzohydrazide
Furan-2-carbaldehyde<smiles>O=C(N/N=C/c1ccco1)c1ccccc1</smiles>

$N^{\prime}$-((Furan-2-yl)methylene)benzohydrazide
L5<smiles>CC(=O)c1c(O)oc(C)cc1=O</smiles>
3-Acetyl-2-hydroxy-6-methyl-4H-pyran-4-one
$-\mathrm{H}_{2} \mathrm{O}$<smiles>C/C(=N\NC(=O)c1ccccc1Br)c1c(O)oc(C)cc1=O</smiles>

2-Hydroxy- $N^{\prime}$-(1-(2-hydroxy-6-methyl-4-oxo-4H-pyran-3yl)ethylidene)benzohydrazide

L6

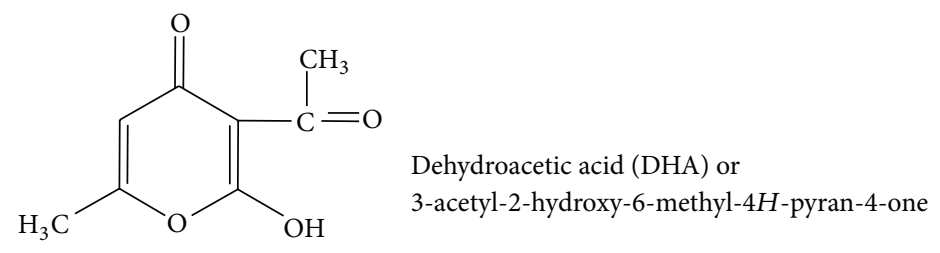


TABLE 1: Elemental composition and physical data of BHFH ligand and its complexes.

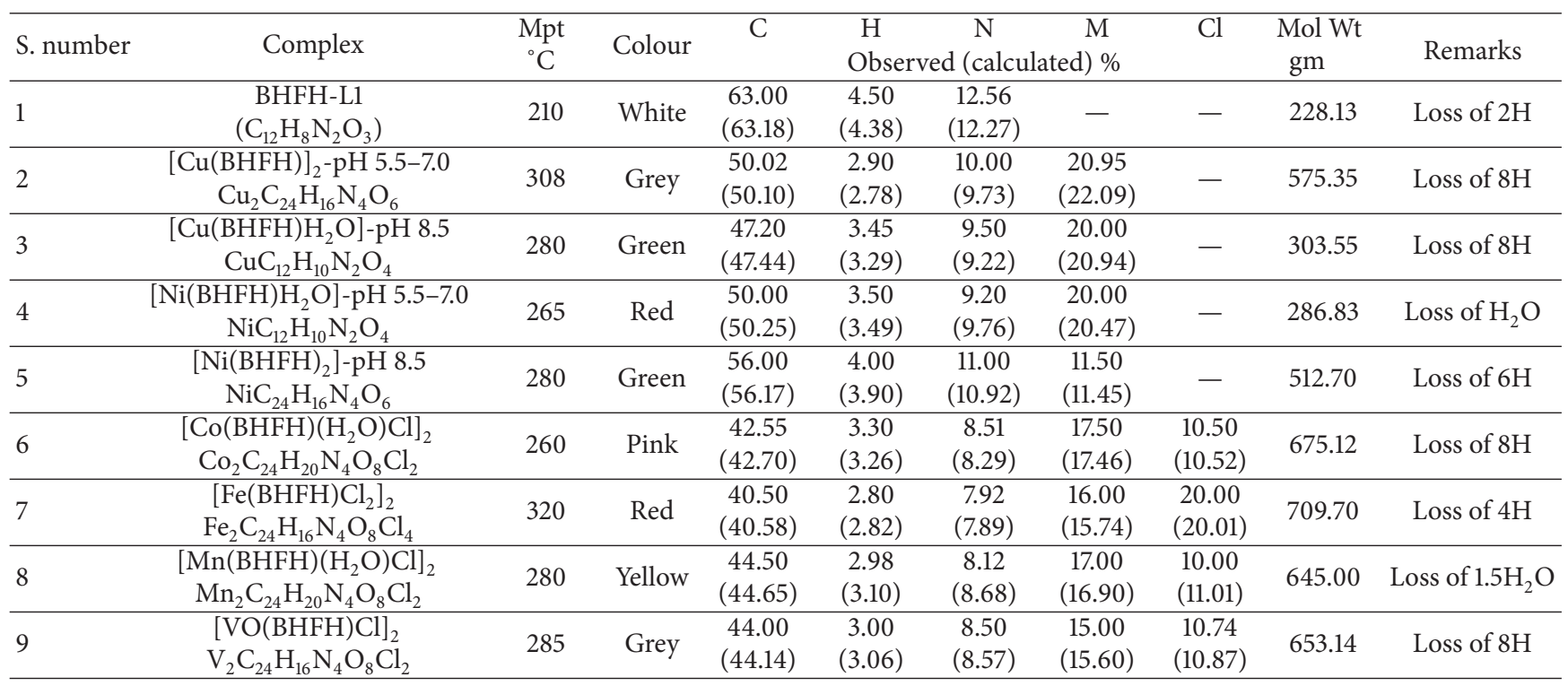

TABLE 2: Elemental composition and physical data of BHEH ligand and its complexes.

\begin{tabular}{|c|c|c|c|c|c|c|c|c|c|c|}
\hline S. number & Complex & $\stackrel{\mathrm{Mpt}}{{ }^{\circ} \mathrm{C}}$ & Colour & $\mathrm{C}$ & $\begin{array}{l}\mathrm{H} \\
\text { Obser }\end{array}$ & $\begin{array}{c}\mathrm{N} \\
\mathrm{d}(\mathrm{calcu}\end{array}$ & $\begin{array}{c}M \\
\text { ted) } \%\end{array}$ & $\mathrm{Cl}$ & $\begin{array}{l}\text { Mol Wt } \\
\text { gm }\end{array}$ & Remarks \\
\hline 1 & $\begin{array}{c}\text { BHEH-L2 } \\
\left(\mathrm{C}_{15} \mathrm{H}_{13} \mathrm{~N}_{2} \mathrm{O}_{4}\right)\end{array}$ & 215 & Yellow & $\begin{array}{c}63.00 \\
(63.18)\end{array}$ & $\begin{array}{c}5.00 \\
(4.91)\end{array}$ & $\begin{array}{c}9.89 \\
(9.82)\end{array}$ & - & - & 285.16 & Loss of $\mathrm{H}$ \\
\hline 2 & $\begin{array}{c}{[\mathrm{Cu}(\mathrm{BHEH}) \mathrm{Cl}]} \\
\mathrm{CuC}_{15} \mathrm{H}_{13} \mathrm{~N}_{2} \mathrm{O}_{4} \mathrm{Cl}\end{array}$ & 305 & Green & $\begin{array}{c}47.05 \\
(47.36)\end{array}$ & $\begin{array}{c}3.50 \\
(3.42) \\
\end{array}$ & $\begin{array}{c}7.50 \\
(7.37)\end{array}$ & $\begin{array}{c}16.00 \\
(16.72)\end{array}$ & $\begin{array}{c}9.50 \\
(9.35)\end{array}$ & 380.10 & Loss of $4 \mathrm{H}$ \\
\hline 3 & $\begin{array}{l}{\left[\mathrm{Ni}(\mathrm{BHEH})_{2}\right]} \\
\mathrm{NiC}_{30} \mathrm{H}_{26} \mathrm{~N}_{4} \mathrm{O}_{8} \\
\end{array}$ & 270 & Red & $\begin{array}{c}57.00 \\
(57.26) \\
\end{array}$ & $\begin{array}{c}4.20 \\
(4.14) \\
\end{array}$ & $\begin{array}{c}8.77 \\
(8.91)\end{array}$ & $\begin{array}{c}9.50 \\
(9.34)\end{array}$ & - & 628.70 & Loss of $2 \mathrm{H}$ \\
\hline 4 & $\begin{array}{l}{\left[\mathrm{Co}(\mathrm{BHEH})_{2}\right]} \\
\mathrm{CoC}_{30} \mathrm{H}_{28} \mathrm{~N}_{4} \mathrm{O}_{8}\end{array}$ & 260 & Brown & $\begin{array}{c}57.50 \\
(57.61) \\
\end{array}$ & $\begin{array}{c}4.35 \\
(4.48) \\
\end{array}$ & $\begin{array}{c}9.01 \\
(8.96) \\
\end{array}$ & $\begin{array}{l}10.00 \\
(9.43)\end{array}$ & - & 630.93 & - \\
\hline 5 & $\begin{array}{c}{\left[\mathrm{Fe}(\mathrm{BHEH})\left(\mathrm{H}_{2} \mathrm{O}\right) \mathrm{Cl}\right]_{2}} \\
\mathrm{Fe}_{2} \mathrm{C}_{30} \mathrm{H}_{30} \mathrm{~N}_{4} \mathrm{O}_{10} \mathrm{Cl}_{2}\end{array}$ & 305 & Black & $\begin{array}{c}45.55 \\
(45.64) \\
\end{array}$ & $\begin{array}{c}4.35 \\
(3.80) \\
\end{array}$ & $\begin{array}{c}7.23 \\
(7.10) \\
\end{array}$ & $\begin{array}{c}14.52 \\
(14.16)\end{array}$ & $\begin{array}{c}9.50 \\
(9.00)\end{array}$ & 788.70 & Loss of $2 \mathrm{H}$ \\
\hline 6 & $\begin{array}{c}{\left[\mathrm{Mn}(\mathrm{BHEH})_{2}\right]} \\
\mathrm{MnC}_{30} \mathrm{H}_{26} \mathrm{~N}_{4} \mathrm{O}_{8}\end{array}$ & 285 & Brown & $\begin{array}{c}58.00 \\
(58.02)\end{array}$ & $\begin{array}{c}3.93 \\
(3.87)\end{array}$ & $\begin{array}{c}9.00 \\
(9.02)\end{array}$ & $\begin{array}{l}10.00 \\
(8.78)\end{array}$ & - & 620.50 & Loss of $4 \mathrm{H}$ \\
\hline 7 & $\begin{array}{c}{[\mathrm{VO}(\mathrm{BHEH}) \mathrm{Cl}]_{2}} \\
\mathrm{~V}_{2} \mathrm{C}_{30} \mathrm{H}_{26} \mathrm{~N}_{4} \mathrm{O}_{10} \mathrm{Cl}_{2}\end{array}$ & 300 & Grey & $\begin{array}{c}44.20 \\
(44.28) \\
\end{array}$ & $\begin{array}{c}3.29 \\
(3.34)\end{array}$ & $\begin{array}{c}7.25 \\
(7.38)\end{array}$ & $\begin{array}{c}12.86 \\
(13.43)\end{array}$ & $\begin{array}{c}9.20 \\
(9.46)\end{array}$ & 758.88 & Loss of $2 \mathrm{C}$ and $2 \mathrm{H}$ \\
\hline
\end{tabular}

TABLE 3: Elemental composition and physical data of HAEP ligand and its complexes.

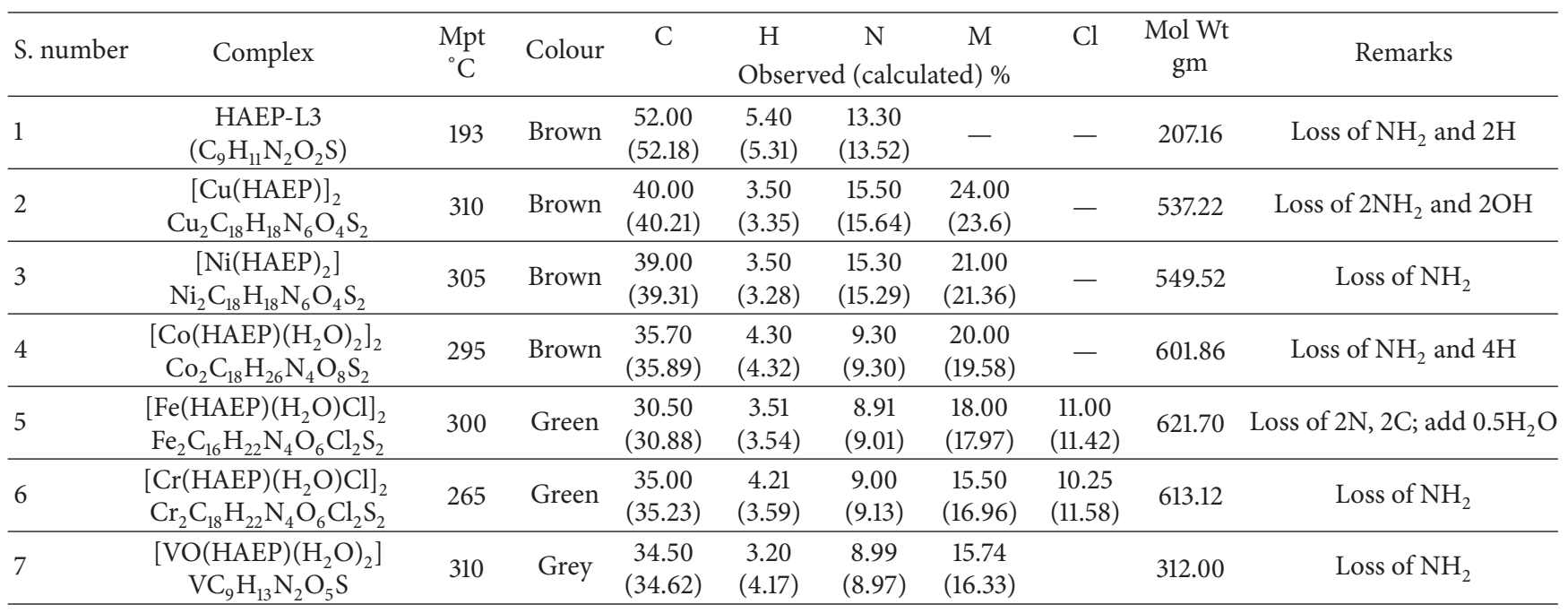


TABLE 4: Elemental composition and physical data of BFH ligand and its complexes.

\begin{tabular}{|c|c|c|c|c|c|c|c|c|c|c|}
\hline \multirow{2}{*}{ S. number } & \multirow{2}{*}{ Complex } & \multirow{2}{*}{${ }^{\mathrm{M} P \mathrm{C}}$} & \multirow{2}{*}{ Colour } & \multirow{2}{*}{\multicolumn{4}{|c|}{$\begin{array}{lcc}\mathrm{H} & \mathrm{N} & \mathrm{M} \\
\text { Observed (calculated) } \%\end{array}$}} & \multirow[t]{2}{*}{$\mathrm{Cl}$} & \multirow{2}{*}{$\begin{array}{l}\text { Mol Wt } \\
\text { gm }\end{array}$} & \multirow{2}{*}{ Remarks } \\
\hline & & & & & & & & & & \\
\hline 1 & $\begin{array}{c}\text { BFH-L4 } \\
\left(\mathrm{C}_{12} \mathrm{H}_{10} \mathrm{~N}_{2} \mathrm{O}_{2}\right)\end{array}$ & 182 & Yellow & $\begin{array}{c}67.50 \\
(67.63) \\
\end{array}$ & $\begin{array}{c}5.00 \\
(4.69) \\
\end{array}$ & $\begin{array}{c}13.00 \\
(13.14) \\
\end{array}$ & - & - & 213.13 & Loss of $\mathrm{H}$ \\
\hline 2 & $\begin{array}{c}{\left[\mathrm{Cr}(\mathrm{BFH})\left(\mathrm{H}_{2} \mathrm{O}\right) \mathrm{Cl}_{2}\right]_{2}} \\
\mathrm{Cr}_{2} \mathrm{C}_{24} \mathrm{H}_{20} \mathrm{~N}_{4} \mathrm{O}_{6} \mathrm{Cl}_{4} \\
\text { pH 5.5-7.0 }\end{array}$ & 270 & Brown & $\begin{array}{c}42.00 \\
(42.42)\end{array}$ & $\begin{array}{c}3.25 \\
(2.95)\end{array}$ & $\begin{array}{c}8.10 \\
(8.25)\end{array}$ & $\begin{array}{c}13.50 \\
(15.32)\end{array}$ & $\begin{array}{c}19.52 \\
(20.91)\end{array}$ & 679.00 & Loss of $1.5 \mathrm{H}_{2} \mathrm{O}$ \\
\hline 3 & $\begin{array}{c}{\left[\mathrm{Cr}(\mathrm{BFH})_{2}\left(\mathrm{H}_{2} \mathrm{O}\right)\right] \mathrm{Cl}_{2}} \\
\mathrm{CrC}_{24} \mathrm{H}_{20} \mathrm{~N}_{4} \mathrm{O}_{5} \mathrm{Cl} \\
\mathrm{pH} 8.5\end{array}$ & 310 & Red & $\begin{array}{c}55.00 \\
(55.38)\end{array}$ & $\begin{array}{c}3.50 \\
(3.85)\end{array}$ & $\begin{array}{l}10.50 \\
(10.77)\end{array}$ & $\begin{array}{l}10.00 \\
(10.00)\end{array}$ & $\begin{array}{c}12.52 \\
(13.65)\end{array}$ & 520.00 & Loss of $2.5 \mathrm{H}_{2} \mathrm{O}$ \\
\hline 4 & $\begin{array}{c}{\left[\mathrm{VO}(\mathrm{BFH})_{2}\left(\mathrm{H}_{2} \mathrm{O}\right)\right]} \\
\mathrm{VC}_{24} \mathrm{H}_{18} \mathrm{~N}_{4} \mathrm{O}_{6}\end{array}$ & 300 & Red & $\begin{array}{c}58.50 \\
(58.42)\end{array}$ & $\begin{array}{c}4.00 \\
(4.06) \\
\end{array}$ & $\begin{array}{c}10.90 \\
(11.36) \\
\end{array}$ & $\begin{array}{c}10.00 \\
(10.33) \\
\end{array}$ & - & 492.94 & Loss of $\mathrm{H}_{2} \mathrm{O}$ \\
\hline
\end{tabular}

TABLE 5: Elemental composition and physical data of BHDH ligand and its complexes.

\begin{tabular}{|c|c|c|c|c|c|c|c|c|c|c|}
\hline \multirow{2}{*}{ S. number } & \multirow{2}{*}{ Complex } & \multirow{2}{*}{${ }^{\circ} \mathrm{CPt}$} & \multirow{2}{*}{ Colour } & \multirow{2}{*}{\multicolumn{4}{|c|}{$\begin{array}{ccc}\mathrm{H} & \mathrm{N} & \mathrm{M} \\
\text { Observed (calculated) } \%\end{array}$}} & \multirow[t]{2}{*}{$\mathrm{Cl}$} & \multirow{2}{*}{$\begin{array}{l}\text { Mo. Wt } \\
\text { gm }\end{array}$} & \multirow{2}{*}{ Remarks } \\
\hline & & & & & & & & & & \\
\hline 1 & $\begin{array}{c}\text { BHDH-L5 } \\
\left(\mathrm{C}_{15} \mathrm{H}_{14} \mathrm{~N}_{2} \mathrm{O}_{5}\right) \\
\end{array}$ & 240 & Yellow & $\begin{array}{c}60.00 \\
(60.02) \\
\end{array}$ & $\begin{array}{c}5.00 \\
(4.66) \\
\end{array}$ & $\begin{array}{c}9.40 \\
(9.33) \\
\end{array}$ & - & - & 300.16 & Loss of $2 \mathrm{H}$ \\
\hline 2 & $\begin{array}{c}{[\mathrm{Cr}(\mathrm{BHDH}) \mathrm{Cl}]_{2}} \\
\mathrm{Cr}_{2} \mathrm{C}_{30} \mathrm{H}_{24} \mathrm{~N}_{4} \mathrm{O}_{10} \mathrm{Cl}_{2} \\
\end{array}$ & 300 & Green & $\begin{array}{c}47.00 \\
(47.06) \\
\end{array}$ & $\begin{array}{c}3.00 \\
(3.14) \\
\end{array}$ & $\begin{array}{c}7.52 \\
(7.32) \\
\end{array}$ & $\begin{array}{c}10.00 \\
(13.59) \\
\end{array}$ & $\begin{array}{c}9.25 \\
(9.28) \\
\end{array}$ & 765.00 & Loss of $2 \mathrm{H}$ \\
\hline 3 & $\begin{array}{c}{\left[\mathrm{VO}(\mathrm{BHDH})\left(\mathrm{H}_{2} \mathrm{O}\right)\right]} \\
\mathrm{VC}_{15} \mathrm{H}_{14} \mathrm{~N}_{2} \mathrm{O}_{7} \\
\end{array}$ & 305 & Green & $\begin{array}{c}40.55 \\
(40.63) \\
\end{array}$ & $\begin{array}{c}3.90 \\
(3.91) \\
\end{array}$ & $\begin{array}{c}7.30 \\
(7.29) \\
\end{array}$ & $\begin{array}{c}13.12 \\
(13.27) \\
\end{array}$ & - & 383.94 & Loss of $2 \mathrm{H}, 2 \mathrm{C}$; add $\mathrm{H}_{2} \mathrm{O}, 4 \mathrm{H}$ \\
\hline
\end{tabular}

as $200 \mathrm{~mL}$ into $10(500 \mathrm{~mL})$ conical flasks containing $2 \mathrm{~g}$ of agar-agar each. All were inoculated and incubated. A set of plates with a standard bactericide, 2-bromo-2-nitro-1, 3propanediol (Bronidiol), for comparison and another set of control plates with distilled water were kept for evaluation of results. All the data are consolidated in Table 20.

\section{Results and Discussion}

Five new ligands were synthesized by mixing the appropriate amine and the aldehyde condensation via a Schiff base reaction (Scheme 1). All of the SBs, thus formed, are crystalline powders white or pale-yellow in colour and are stable to air and moisture. They are found to be soluble in most of the polar solvents like ethanol, methanol, acetone, and so forth and also in bases. All of them were characterized by elemental analyses, melting points (Tables 1-6), and IR spectra (Tables 7-12). The elemental analyses of the ligands show that there is a loss of a few molecules during the $\mathrm{CHN}$ analyses, probably due to the low melting points of the synthesized ligands and the details are given in the remarks column of the Tables 1-6, while the IR spectra show all the expected structural peaks. From the IR data in Table 7, it was analyzed that L1 acts as a tridentate ligand by coordinating through $-\mathrm{O}$ of the deprotonated phenolic group, $-\mathrm{O}$ of another deprotonated-OH group formed due to enolization, and $-\mathrm{N}$ of the azomethine group. Table 8 shows that the $\mathrm{L} 2$ acts as a tridentate ligand similar to $\mathrm{L} 1$ and the $-\mathrm{OH}$ groups of the resacetophenone moiety do not participate in coordination. Table 9 gives the data for L3 which enolizes and acts as a tridentate ligand coordinating through the $-\mathrm{O}$ of the deprotonated phenolic group, $-\mathrm{S}$ of the $-\mathrm{SH}$ group after deprotonation, and $-\mathrm{N}$ of the azomethine group. Thus it is found to remain in the "thione" form and not in the "thiol" form $[65,66]$ in the solid state. Table 10 gives details on L4 acting as a bidentate ligand with $-\mathrm{O}$ and $-\mathrm{N}$ donors. Table 11 shows the details of L5 acting as a tetradentate bound through three -O's and one $-\mathrm{N}$ and L6, not a Schiff base but used directly for complexation, binds through carbonyl $-\mathrm{O}$ atom and -O of phenolic group as is shown in Table 12.

They were used to make complexes with $\mathrm{Cu}(\mathrm{II}), \mathrm{Ni}(\mathrm{II})$, $\mathrm{Co}(\mathrm{II}), \mathrm{Fe}(\mathrm{III}), \mathrm{Mn}(\mathrm{II}), \mathrm{Cr}(\mathrm{III})$, and VO(II) metal ions. Generally all the metal complexes were synthesized in alcoholic solutions at room temperature or by reflux at $\mathrm{pH} 5.5$ or 8.5. These were characterized by the usual analytical and spectroscopic methods. All the complexes formed with the respective ligands have been shown to coordinate with the denticity mentioned above and the shift of the coordinating atoms is also shown in Tables $7-12$, thus confirming the formation of stable metal chelates with the new Schiff bases and DHA, L6. The physical data, elemental analyses are also given in Tables 1-6 for all the complexes synthesized. These data for all the complexes also show a loss of a few molecules during the analysis of $\mathrm{CHN}$, probably due to the lower decomposition temperature, while the IR spectra show all the expected structural peaks. Some of the complexes have one, two, or four coordinated water molecules which were analysed by TGA analyses. The variable temperature data of these complexes from room temperature to decomposition of the complex and the loss in weight of the material taken confirm the percentage of coordinated water which is present in the complex composition predicted.

The chemistry of ligands upon binding to different metal atoms leads to the formation of expected four and/or six coordinate complexes and the salient features are discussed 
TABLE 6: Elemental composition and physical data of DHA ligand and its complexes.

\begin{tabular}{|c|c|c|c|c|c|c|c|c|}
\hline S. number & Complex & $\begin{array}{l}\mathrm{MPt} \\
{ }^{\circ} \mathrm{C}\end{array}$ & Colour & \multicolumn{2}{|c|}{ Observed (calculated) \% } & $\%$ & $\begin{array}{c}\text { Mol Wt } \\
\text { gm }\end{array}$ & Remarks \\
\hline 1 & $\begin{array}{l}\text { DHA-L6 } \\
\mathrm{C}_{8} \mathrm{H}_{8} \mathrm{O}_{4} \\
\end{array}$ & 109 & Colorless & $\begin{array}{c}57.00 \\
(57.17) \\
\end{array}$ & $\begin{array}{c}5.00 \\
(4.76) \\
\end{array}$ & - & 168.08 & - \\
\hline 2 & $\begin{array}{l}{\left[\mathrm{Cr}(\mathrm{DHA})_{3}\right]} \\
\mathrm{CrC}_{24} \mathrm{H}_{24} \mathrm{O}_{12}\end{array}$ & 285 & Green & $\begin{array}{c}55.00 \\
(55.41) \\
\end{array}$ & $\begin{array}{c}4.25 \\
(4.61) \\
\end{array}$ & $\begin{array}{c}10.00 \\
(10.00) \\
\end{array}$ & 520.26 & Loss of two $\mathrm{H}_{2} \mathrm{O}$ \\
\hline 3 & $\begin{array}{c}{\left[\mathrm{VO}(\mathrm{DHA})_{2}\left(\mathrm{H}_{2} \mathrm{O}\right)\right]} \\
\mathrm{VC}_{16} \mathrm{H}_{18} \mathrm{O}_{10}\end{array}$ & 305 & Green & $\begin{array}{c}45.50 \\
(45.61) \\
\end{array}$ & - & $\begin{array}{c}11.75 \\
(12.10) \\
\end{array}$ & 420.94 & - \\
\hline
\end{tabular}

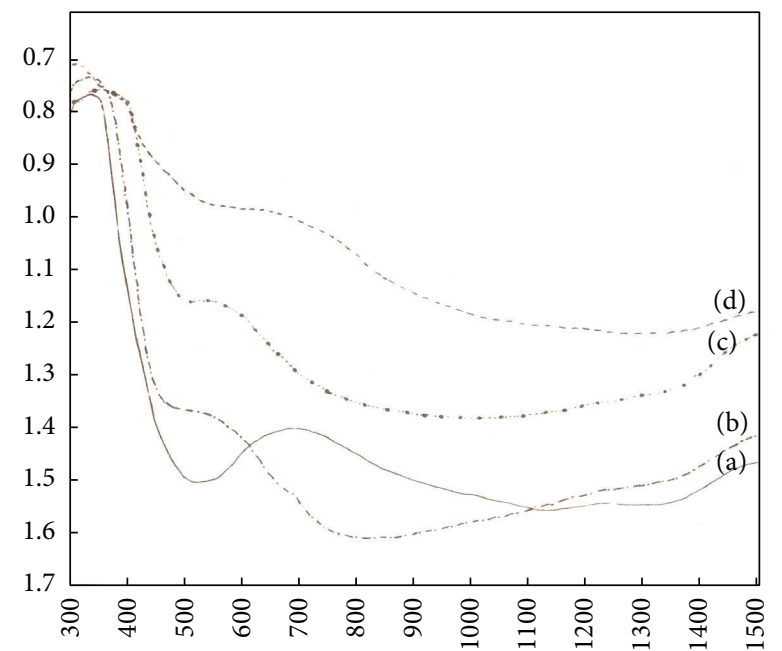

Figure 1: Electronic (MULL) spectra of OXOVANADIUM(N) complexes of (a) BHFH-[Vo(BHFH) $(\mathrm{Cl})]_{2}$; (b) BHEH-[Vo(BHDH) $(\mathrm{Cl})]_{2} ;$ (c) DHA-[Vo(DHA $\left.)_{2}\left(\mathrm{H}_{2} \mathrm{O}\right)\right]$.

below based on the collected electronic and magnetic data. The data are presented in Tables 13-19 and Figures 1-8 for different metal ions.

3.1. $V O(I I)$ Complexes. All the OXOVANADIUM complexes are highly coloured, fine amorphous powders. They are stable to air, moisture and insoluble in water and other common organic polar and nonpolar solvents. They all decompose above $300^{\circ} \mathrm{C}$ (except complex of $\mathrm{L} 1$ at $285^{\circ} \mathrm{C}$ ). V complex with L4 showed loss of weight starting at $52^{\circ} \mathrm{C}(0.0006 \mathrm{gm})$ and decomposed at $300^{\circ} \mathrm{C}(0.0090 \mathrm{gm})$, complex with $\mathrm{L} 3$ at $50^{\circ} \mathrm{C}$ $(0.0004 \mathrm{gm})$ and decomposed at $310^{\circ} \mathrm{C}(0.0088 \mathrm{gm})$, complex with $\mathrm{L} 5$ at $50^{\circ} \mathrm{C}(0.0008 \mathrm{gm})$ and decomposed at $305^{\circ} \mathrm{C}$ $(0.0096 \mathrm{gm})$, and complex with $\mathrm{L} 6$ at $50^{\circ} \mathrm{C}(0.0009 \mathrm{gm})$ and decomposed at $305^{\circ} \mathrm{C}(0.0099 \mathrm{gm})$ in the thermal analysis, thus confirming one or two molecules of water coordination in the complexes as per the composition predicted.

All the VO(II) complexes are paramagnetic as shown in Table 13; Figures 1 and 2. The values of L6, L3, and L5 based complexes are in agreement with the expected spinonly value of $1.73 \mathrm{BM}$ at RT. However, the complexes with L1 and L2 have shown lower values 1.5-1.6 BM may be due to low symmetry expected at $1.73 \mathrm{BM}$ when the orbital angular contribution is almost quenched [67] and may occur due to

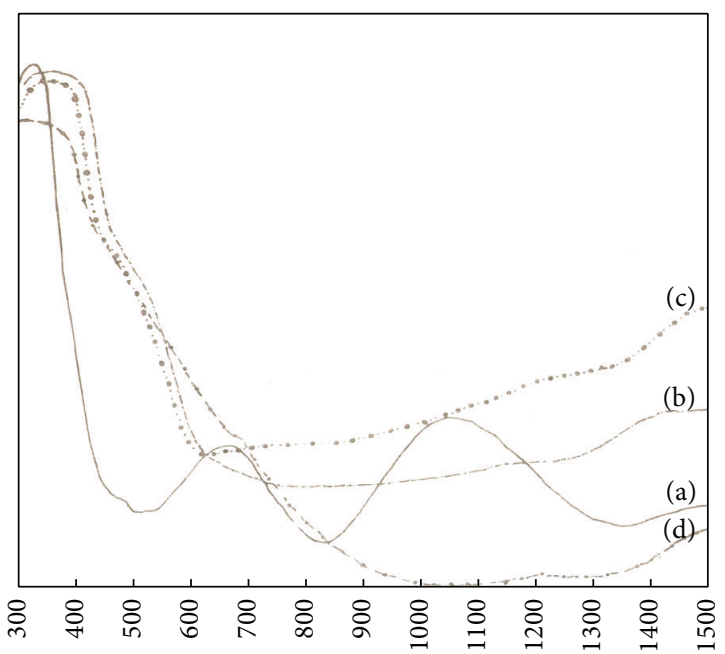

FIGURE 2: Electronic (MULL) spectra of OXOVANADIUM(II) complexes of (a) BHDH-[Vo(BHDH) $\left.\left(\mathrm{H}_{2} \mathrm{O}\right)\right]$; (b) HAEP-[Vo(HAEP) $\left.\left(\mathrm{H}_{2} \mathrm{O}\right)_{2}\right]$; (c) BFH-[Vo(BFH $\left.)_{2}\left(\mathrm{H}_{2} \mathrm{O}\right)\right]$.

the presence of exchange coupled antiferromagnetism [68]. Several reports indicate such behavior [69-71]. Hence, they are assigned binuclear structures.

Electronic spectra show three bands below $30,000 \mathrm{~cm}^{-1}$ at $\mathrm{RT}$ in diffuse reflectance mull data as given in Table 13 corresponding to octahedral symmetry (Oh) with tetragonal distortion. The bands, transitions, molecular structure, and the predicted geometry are given in Table 13. A few complexes may also show a vibrational structure with a spacing of $700 \mathrm{~cm}^{-1}$ at the $2 \mathrm{~B} 2 \rightarrow 2 \mathrm{E}$ transition band, corresponding to the $\mathrm{V}=\mathrm{O}$ stretching frequency in the excited state, which is not clearly observed.

3.2. $\mathrm{Cr}(\mathrm{III})$ Complexes. All the $\mathrm{Cr}$ (III) complexes are coloured solids and they are stable to air and moisture. They are insoluble in water and in most of the common organic solvents like methanol, ethanol, benzene, acetone, and so forth. Hence, conductivity could not be measured due to the insolubility. $\mathrm{Cr}$ complex with $\mathrm{L} 4$ at lower $\mathrm{pH}$ showed loss of weight starting at $110^{\circ} \mathrm{C}(0.0005 \mathrm{gm})$ and decomposed at $270^{\circ} \mathrm{C}(0.0091 \mathrm{gm})$, complex with $\mathrm{L} 4$ at higher $\mathrm{pH}$ at $52^{\circ} \mathrm{C}$ $(0.0005 \mathrm{gm})$ and decomposed at $310^{\circ} \mathrm{C}(0.0091 \mathrm{gm})$, and complex with $\mathrm{L} 3$ at $52^{\circ} \mathrm{C}(0.0005 \mathrm{gm})$ and decomposed at $265^{\circ} \mathrm{C}(0.0091 \mathrm{gm})$ in the thermal analysis. Thus, confirming 


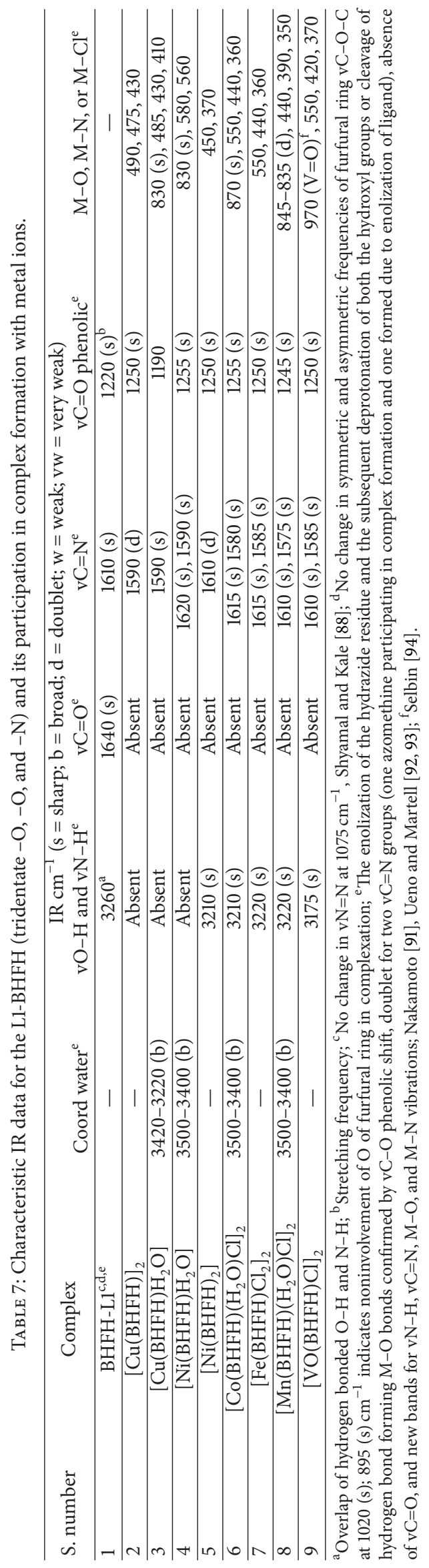


TABLE 8: Characteristic IR data for the L2-BHEH (tridentate $-\mathrm{O},-\mathrm{O}$, and $-\mathrm{N}$ ) and its participation in complex formation with metal ions.

\begin{tabular}{|c|c|c|c|c|c|c|c|c|}
\hline \multirow{2}{*}{ S. number } & \multirow{2}{*}{ Complex } & \multicolumn{7}{|c|}{ IR $\mathrm{cm}^{-1}$ ( $\mathrm{s}=$ sharp; $\mathrm{b}=$ broad; $\mathrm{d}=$ doublet; $\mathrm{w}=$ weak; $\mathrm{vw}=$ very weak $)$} \\
\hline & & Coord water & $\mathrm{vO}-\mathrm{H}^{\mathrm{c}}$ & $\mathrm{vN}-\mathrm{H}^{\mathrm{c}}$ & $\mathrm{vC}=\mathrm{O}^{\mathrm{d}}$ & $\mathrm{vC}=\mathrm{N}^{\mathrm{d}}$ & $\mathrm{vC}=\mathrm{O}$ phenolic ${ }^{\mathrm{e}}$ & $\mathrm{M}-\mathrm{O}$ or $\mathrm{M}-\mathrm{N}$ or $\mathrm{M}-\mathrm{Cl}^{\mathrm{f}}$ \\
\hline 1 & BHEH-L2 ${ }^{\mathrm{g}}$ & - & $3330(\mathrm{~b})^{\mathrm{a}}$ & $3260(\mathrm{~b})^{\mathrm{b}}$ & $1650(\mathrm{~s})$ & $1610(s)$ & $1240(\mathrm{~s})$ & - \\
\hline 2 & {$[\mathrm{Cu}(\mathrm{BHEH}) \mathrm{Cl}]$} & - & $3460(\mathrm{~b})$ & $3340(\mathrm{~b})$ & $1600(\mathrm{~s})$ & $1585(\mathrm{~s})$ & $1255(\mathrm{~s})$ & $690,510,270$ \\
\hline 3 & {$\left[\mathrm{Ni}(\mathrm{BHEH})_{2}\right]$} & - & $3600(b)$ & $3340(\mathrm{~b})$ & $1620(\mathrm{~s})$ & $1600(\mathrm{~s})$ & $1255(\mathrm{~s})$ & 500,380 \\
\hline 4 & {$\left[\mathrm{Co}(\mathrm{BHEH})_{2}\right]$} & - & $3450(\mathrm{~b})$ & $3280(\mathrm{~s})$ & $1620(\mathrm{~s})$ & $1600(s)$ & $1255(\mathrm{~s})$ & $650-400$ \\
\hline 5 & {$\left[\mathrm{Fe}(\mathrm{BHEH})\left(\mathrm{H}_{2} \mathrm{O}\right) \mathrm{Cl}\right]_{2}$} & $3500-3450(\mathrm{~b})$ & - & $3340(\mathrm{~b})$ & $1605(s)$ & $1580(\mathrm{~s})$ & $1255(\mathrm{~s})$ & $840(\mathrm{~s}), 620,580,490$ \\
\hline 6 & {$\left[\mathrm{Mn}(\mathrm{BHEH})_{2}\right]$} & - & $3460(b)$ & $3280(\mathrm{~s})$ & $1620(d)$ & $1600(s)$ & $1255(\mathrm{~s})$ & $650-400$ \\
\hline 7 & {$[\mathrm{VO}(\mathrm{BHEH}) \mathrm{Cl}]_{2}$} & - & $3500(\mathrm{w})$ & $3260(b)$ & $1600(\mathrm{~s})$ & $1590(\mathrm{~s})$ & $1260(\mathrm{~s})$ & $970(\mathrm{~V}=\mathrm{O}), 570,520,340$ \\
\hline
\end{tabular}

${ }^{\mathrm{a}}$ Intramolecular hydrogen bonding; ${ }^{\mathrm{b}}$ Hydrogen bonding; ${ }^{\mathrm{c}}$ Shift indicates cleavage of intramolecular $\mathrm{H}$ bonds after complex formation; ${ }^{\mathrm{d}}$ Involvement of $\mathrm{O}$ of carbonyl group and $\mathrm{N}$ of azomethine group in complex formation, Watt and Dowes [95]; Truter and Rutherford [96]; Cotton and Wilkinson [97]; ${ }^{\mathrm{e} D a v i s o n}$ and Christie [98]; Kubo et al. [99]; indicates deprotonation of phenolic $\mathrm{OH}$ and binding to $\mathrm{M}$; ${ }^{\mathrm{f}}$ Nakamoto [91, 100] and Selbin [94]; ${ }^{\mathrm{g}} \mathrm{No}$ change in vN-N at $1040(\mathrm{w}) \mathrm{cm}^{-1}$.

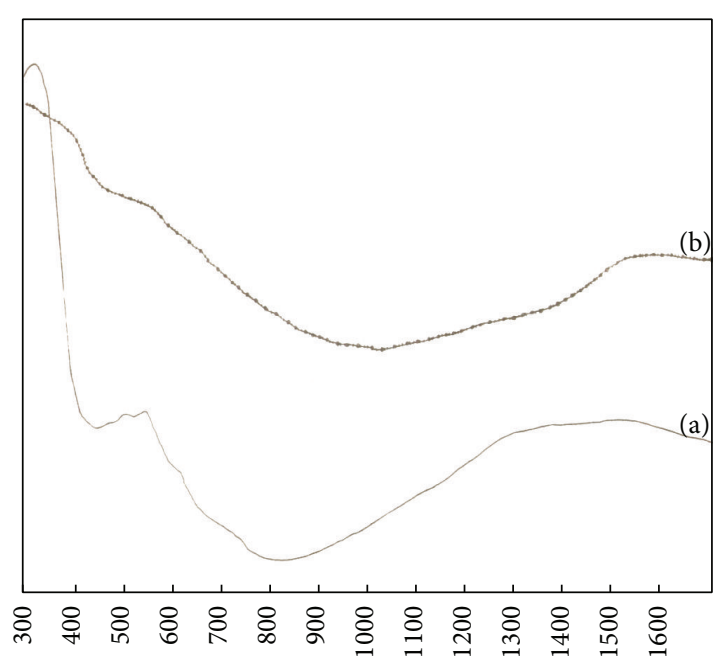

Figure 3: Electronic (MULL) spectra of CHROMIUM(III) complexes of (a) DHA- $\left[\mathrm{Cr}(\mathrm{DHA})_{3}\right]$; (b) BFH-[Cr(BFH $\left.)_{2}(\mathrm{Cl})\left(\mathrm{H}_{2} \mathrm{O}\right)\right]$; (c) HAEP- $\left[\mathrm{Cr}(\mathrm{HAEP})(\mathrm{Cl})\left(\mathrm{H}_{2} \mathrm{O}\right)\right]_{2}$; (d) BHDH- $[\mathrm{Cr}(\mathrm{BHDH})(\mathrm{Cl})]_{2}$.

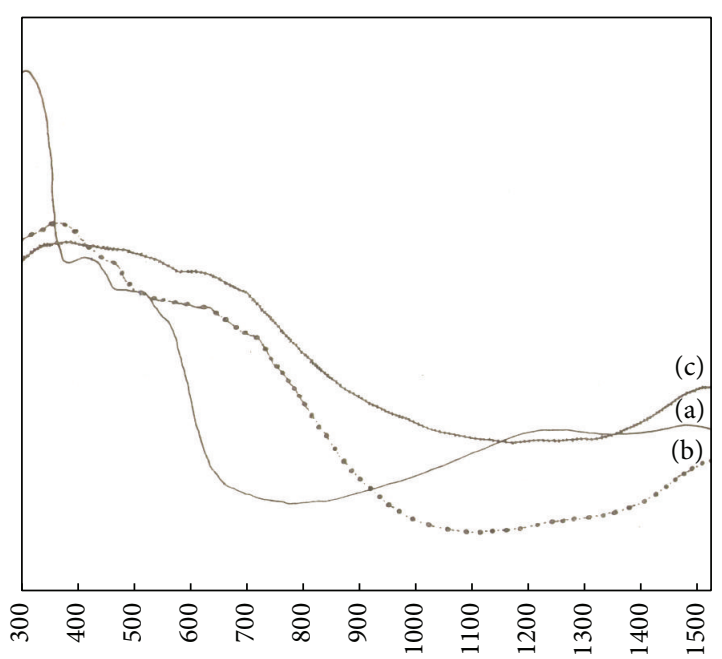

Figure 4: Electronic (MULL) spectra of MANGANESE(II) complexes of (a) BHFH-[Mn $\left.(\mathrm{BHFH})(\mathrm{Cl})\left(\mathrm{H}_{2} \mathrm{O}\right)\right]_{2}$; (b) BHEH-[Mn $\left.(\mathrm{BHEH})_{2}\right]$.

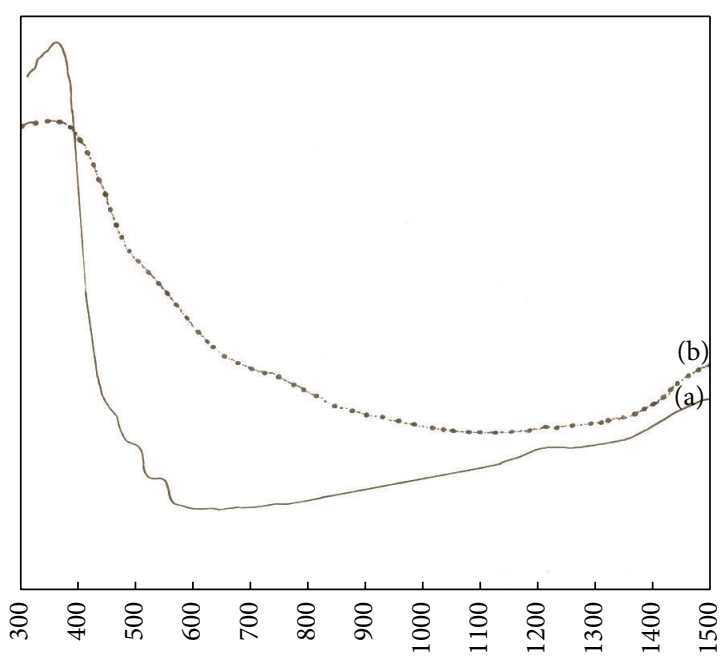

FIGURE 5: Electronic (MULL) spectra of IRON(III) complex of (a) BHFH- $\left[\mathrm{Fe}(\mathrm{BHFH})(\mathrm{Cl})_{2}\right]_{2}$; (b) BHEH- $\left[\mathrm{Fe}(\mathrm{BHEH})(\mathrm{Cl})\left(\mathrm{H}_{2} \mathrm{O}\right)\right]_{2}$; (c) HAEP- $\left[\mathrm{Fe}(\mathrm{HAEP})(\mathrm{Cl})\left(\mathrm{H}_{2} \mathrm{O}\right)_{2}\right]_{2}$.

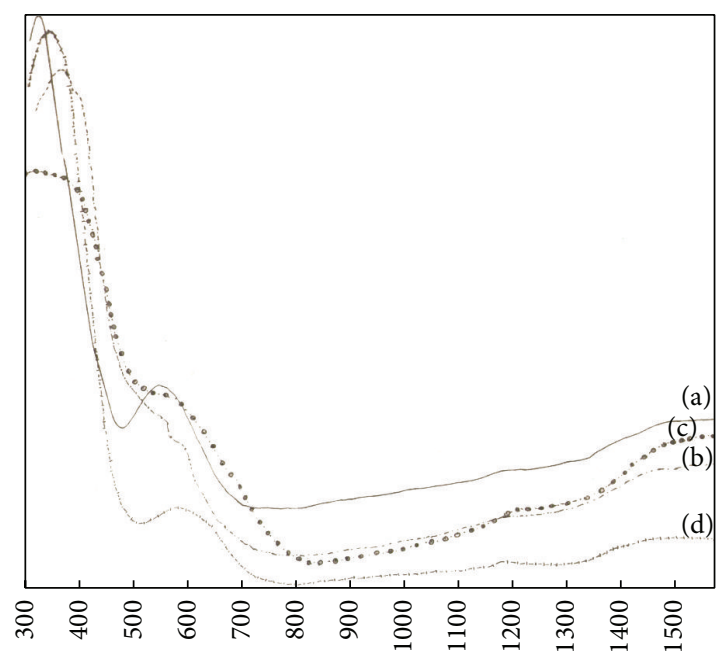

FIGURE 6: Electronic (MULL) spectra of COBALT(II) complexes of (a) BHFH $\left[\mathrm{Co}(\mathrm{BHFH})(\mathrm{Cl})\left(\mathrm{H}_{2} \mathrm{O}\right)\right]_{2}$; (b) HAEP $[\mathrm{Co}(\mathrm{HAEP})$ $\left.\left(\mathrm{H}_{2} \mathrm{O}\right)_{2}\right]_{2}$. 


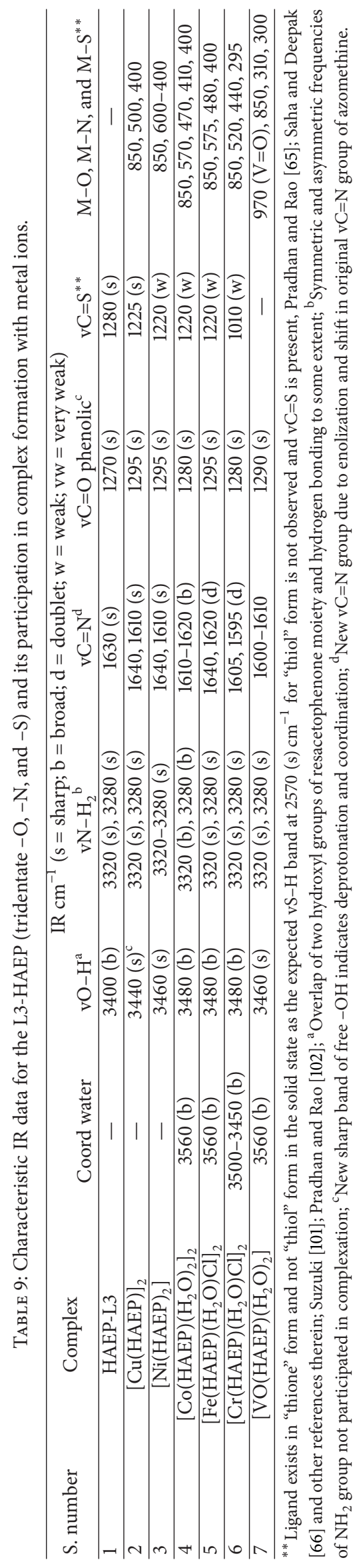


TABLE 10: Characteristic IR data for the L4-BFH (bidentate $-\mathrm{O},-\mathrm{N}$ ) and its participation in complex formation with metal ions.

\begin{tabular}{|c|c|c|c|c|c|c|}
\hline \multirow{2}{*}{ S. number } & \multirow{2}{*}{ Complex } & \multicolumn{5}{|c|}{ IR $\mathrm{cm}^{-1}$ ( $\mathrm{s}=$ sharp; $\mathrm{b}=$ broad; $\mathrm{d}=$ doublet; $\mathrm{w}=$ weak; $\mathrm{vw}=$ very weak) } \\
\hline & & Coord water & $\mathrm{vN}-\mathrm{H}$ & $\mathrm{vC}=\mathrm{O}$ & $\mathrm{vC}=\mathrm{N}^{\mathrm{d}}$ & $\mathrm{M}-\mathrm{O}, \mathrm{M}-\mathrm{N}, \mathrm{M}-\mathrm{Cl}^{\mathrm{e}}$ \\
\hline 1 & BFH-L4 ${ }^{\mathrm{b}}$ & - & $3240(\mathrm{~s})^{\mathrm{a}}$ & $1650(\mathrm{~s})$ & $1620(\mathrm{~s})$ & - \\
\hline 2 & {$\left[\mathrm{Cr}(\mathrm{BFH})\left(\mathrm{H}_{2} \mathrm{O}\right) \mathrm{Cl}_{2}\right]_{2}$} & $3550-3450$ & Absent $^{\mathrm{c}}$ & - & $1610(\mathrm{~s}), 1590(\mathrm{~s})$ & $830,570,400(\mathrm{~s}), 300(\mathrm{vw})$ \\
\hline 3 & {$\left[\mathrm{Cr}(\mathrm{BFH})_{2}\left(\mathrm{H}_{2} \mathrm{O}\right) \mathrm{Cl}\right]$} & $3550-3450$ & Absent $^{\mathrm{c}}$ & - & $1610(\mathrm{~s}) 1590(\mathrm{~s})$ & $840,575,395(\mathrm{~s}), 300(\mathrm{vw})$ \\
\hline 4 & {$\left[\mathrm{VO}(\mathrm{BFH})_{2}\left(\mathrm{H}_{2} \mathrm{O}\right)\right]$} & $3550-3450(\mathrm{~b})$ & Absent $^{c}$ & - & $1600-1610(\mathrm{~s})$ & $970(\mathrm{~V}=\mathrm{O}), 810,440,350$ \\
\hline
\end{tabular}

${ }^{a}$ Hydrazone moiety; ${ }^{b}$ No shift in symmetric and asymmetric stretching frequencies of furfural ring oxygen at $1020(\mathrm{~s}), 895(\mathrm{~s}) \mathrm{cm}^{-1}$ and N-N at $1040(\mathrm{w})$ indicates no involvement in complex formation; ${ }^{\mathrm{c}}$ Absence of $\mathrm{vN}-\mathrm{H}$ band suggests enolization of the ligand which is confirmed by disappearance of strong $\mathrm{vC}=\mathrm{O}$ band; ${ }^{\mathrm{d}}$ Shift indicates participation of $-\mathrm{N}$ of azomethine group in coordination; ${ }^{\mathrm{e}}$ Nakamoto [91, 100] and Selbin [94].

TABLE 11: Characteristic IR data for the $\mathrm{L} 5-\mathrm{BHDH}$ (tetradentate $-\mathrm{O},-\mathrm{O},-\mathrm{N}$, and $-\mathrm{O}$ ) and its participation in complex formation with metal ions.

\begin{tabular}{|c|c|c|c|c|c|c|c|c|}
\hline \multirow{2}{*}{ S. number } & \multirow{2}{*}{ Complex } & \multicolumn{7}{|c|}{ IR $\mathrm{cm}^{-1}$ ( $\mathrm{s}=$ sharp; $\mathrm{b}=$ broad; $\mathrm{d}=$ doublet; $\mathrm{w}=$ weak; $\mathrm{vw}=$ very weak $)$} \\
\hline & & Coord water & $\mathrm{vO}-\mathrm{H}$ & vN-H & $\mathrm{vC}=\mathrm{O}$ & $\mathrm{vC}=\mathrm{N}$ & $\mathrm{vC}-\mathrm{O}$ phenolic & $\mathrm{M}-\mathrm{O}, \mathrm{M}-\mathrm{N}$, or $\mathrm{M}-\mathrm{Cl}$ \\
\hline 1 & $\mathrm{BHDH}_{-\mathrm{L} 5^{\mathrm{C}}}$ & - & $3350-3400(b)^{a}$ & $3280(\mathrm{~s})$ & $1655(\mathrm{~s})$ & $1600(s)$ & $1260(\mathrm{~s})$ & - \\
\hline 2 & {$[\mathrm{Cr}(\mathrm{BHDH}) \mathrm{Cl}]_{2}$} & - & Absent $^{\mathrm{b}}$ & $3280(\mathrm{~s})$ & $1635(\mathrm{~s})$ & $1580(\mathrm{~s})$ & $1300-1310(\mathrm{~d})$ & $550(\mathrm{w}), 435,310,295(\mathrm{w})$ \\
\hline 3 & {$\left[\mathrm{VO}(\mathrm{BHDH})\left(\mathrm{H}_{2} \mathrm{O}\right)\right]$} & $3500-3450(b)$ & Absent $^{\mathrm{b}}$ & $3280(\mathrm{~s})$ & $1610(s)$ & $1575(\mathrm{~s})$ & $1270(\mathrm{~s})$ & $\begin{array}{c}970(\mathrm{~V}=\mathrm{O}), 820(\mathrm{~s}), 520 \\
470,440,340\end{array}$ \\
\hline
\end{tabular}

${ }^{a}$ Inter and intramolecular hydrogen bonding; ${ }^{b}$ The breakage of hydrogen bonding and the deprotonation of both the hydroxyl groups (phenolic), that is, hydrazide $-\mathrm{OH}$ and pyrone $-\mathrm{OH}$ and their $\mathrm{M}-\mathrm{O}$ coordination; ${ }^{\mathrm{c}} \mathrm{No}$ shift of lactone $\mathrm{vC}=\mathrm{O}$ at $1710(\mathrm{~s}) \mathrm{cm}^{-1}$; and $\mathrm{vC}-\mathrm{O}-\mathrm{C}$ at 1010 (s) $\mathrm{cm}^{-1}$ suggests noninvolvement in complex formation; shift of hydrazide, phenolic $\mathrm{vC}-\mathrm{O}$ and $\mathrm{vC}=\mathrm{N}$ indicate participation in complexation.

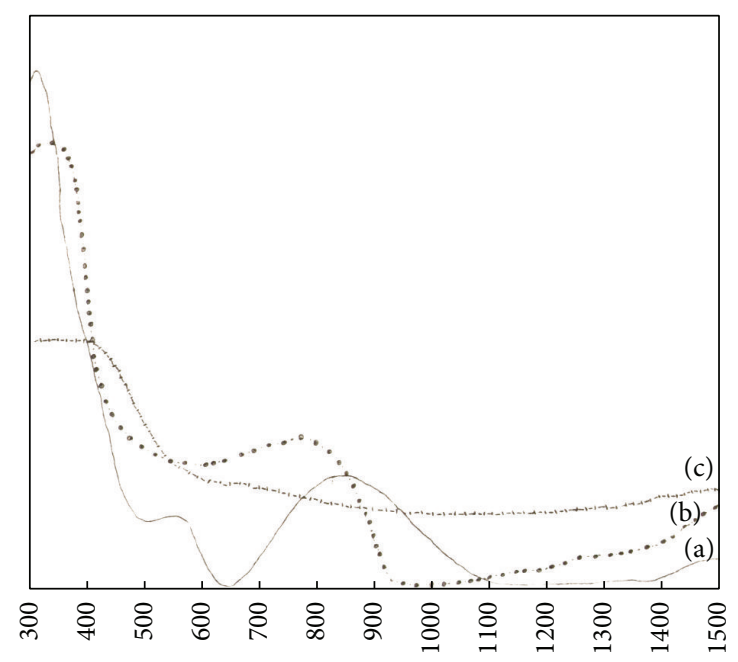

FIGURE 7: Electronic (MULL) spectra of NICKEL(II) complexes of (a) BHFH (AT ph 8.5) $[\mathrm{Ni}(\mathrm{BHFH})]_{2}$; (b) BHFH (AT ph 5.5-7.0) $\left[\mathrm{Ni}(\mathrm{BHFH})\left(\mathrm{H}_{2} \mathrm{O}\right)\right]$; (c) $\mathrm{BHEH}\left[\mathrm{Ni}(\mathrm{BHEH})_{2}\right]$; (d) HAEP $[\mathrm{Ni}(\mathrm{HAEP})]_{2}$.

one or two molecules of water coordination in the complexes as per the composition predicted.

The Cr(III) complexes are synthesized with L3, L4, L5, and L6 and are characterized [72, 73] as having Oh geometry as shown in Table 14; Figure 3. The magnetic moments of L6 and $\mathrm{L} 4$ (prepared at $\mathrm{pH} 8.5$ ) at RT are close to the expected spin-only value for $\mathrm{Oh}$ complexes of $\mathrm{Cr}$ (III) [72-75]. The other complexes show lower values and so may be due to metal-metal interactions with binuclear bridge structures. All the electronic spectra for several greenish $\mathrm{Cr}$ (III) complexes

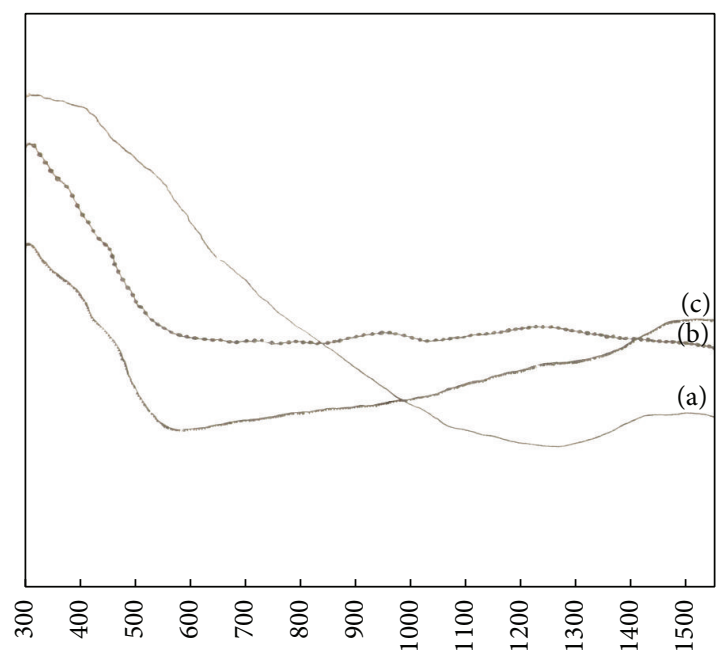

FIGURE 8: Electronic (MULL) spectra of Copper(II) complexes of (a) BHFH (AT ph 5.5-7.0)-[Cu(BHFH) $]_{2}$; (b) BHFH (AT ph 8.5)-[Cu(BHFH) $\left.\left(\mathrm{H}_{2} \mathrm{O}\right)\right]$; (c) BHEH-[Cu(BHEH) $\left.(\mathrm{Cl})\right]$; (d) HAEP$[\mathrm{Cu}(\mathrm{HAEP})]_{2}$.

fit with very large number of such complexes studied and surveyed. However in the present case, the highest energy band is found to be obscured due to the dark colour of all the complexes.

3.3. $\mathrm{Mn}(\mathrm{II})$ Complexes. The $\mathrm{Mn}(\mathrm{II})$ complex of $\mathrm{L} 1$ is a fine powder, light-yellow in colour and decomposed at $280^{\circ} \mathrm{C}$ without melting. The $\mathrm{Mn}$ (II) complex of $\mathrm{L} 2$ is a dark-brown powder decomposed at $286^{\circ} \mathrm{C}$. Both the compounds are very stable in air and moisture and are insoluble in water and 
TABLE 12: Characteristic IR data for the ligand DHA (bidentate -O, $-\mathrm{O}$ ) and its participation in complex formation with metal ions.

\begin{tabular}{lccccccc}
\hline \multirow{2}{*}{ S. number } & \multirow{2}{*}{ Complex } & \multicolumn{6}{c}{$\mathrm{IR} \mathrm{cm}^{-1}(\mathrm{~s}=$ sharp; $\mathrm{b}=$ broad; $\mathrm{d}=$ doublet; $\mathrm{w}=$ weak; vw = very weak) } \\
& & Coord water & vO-H & vC=O (lactone) & vC=O & vC-O phenolic & M-O \\
\hline 1 & DHA-L6 $^{\mathrm{b}}$ & - & $3030(\mathrm{~s})^{\mathrm{a}}$ & $1710(\mathrm{~s})$ & $1655(\mathrm{~s})$ & $1265(\mathrm{~s})$ & - \\
\hline 2 & {$\left[\mathrm{Cr}(\mathrm{DHA})_{3}\right]$} & - & Absent $^{\mathrm{c}}$ & $1740(\mathrm{~s})$ & $1635(\mathrm{~s})$ & $1280(\mathrm{~s})$ & 480,440 \\
\hline 3 & {$\left[\mathrm{VO}(\mathrm{DHA})_{2}\left(\mathrm{H}_{2} \mathrm{O}\right)\right]$} & $3500-3400(\mathrm{~b})$ & Absent $^{\mathrm{c}}$ & $1740(\mathrm{~s})$ & $1640(\mathrm{~s})$ & $1290(\mathrm{~s})$ & $910(\mathrm{~V}=\mathrm{O})^{\mathrm{d}}, 850,480,440$ \\
\hline
\end{tabular}

${ }^{\mathrm{a}}$ Intramolecular hydrogen bonded; ${ }^{\mathrm{b}} \mathrm{No}$ shift in vC-O-C indicates noninvolvement in complex formation, Mahesh and Gupta [103]; ${ }^{\mathrm{c}} \mathrm{Cleavage}$ of hydrogen bonding due to complexation, ${ }^{\mathrm{d}}$ Selbin [94].

in common organic solvents like methanol, ethanol, chloroform, benzene, and so forth. Mn complex with L1 at lower $\mathrm{pH}$ showed loss of weight starting at $56^{\circ} \mathrm{C}(0.0014 \mathrm{gm})$ and decomposed at $280^{\circ} \mathrm{C}(0.0205 \mathrm{gm})$ in the thermal analysis, thus confirming a molecule of water coordination in the complex as per the composition predicted.

As can be seen from Table 15; Figure 4, Mn(II) complex of L1 shows subnormal magnetic moment which may be due to metal-metal interactions or due to spin-exchange or superexchange in the solid state [76,77]. The Mn(II) complex of L2 is $5.92 \mathrm{BM}$ expected region for high-spin Oh $\mathrm{Mn}$ (II) complexes $[72,73]$. The electronic spectra are consistent with the Oh symmetry in both the cases.

3.4. Fe(III) Complexes. All the complexes are dark coloured and fine amorphous powders. All decomposed above $300^{\circ} \mathrm{C}$ are very stable to air, moisture and insoluble in most of the common organic solvents like acetone, methanol, ethanol, and so forth. They are soluble to some extent in solvents like 1-4 dioxane, dimethylformamide, and dimethyl sulfoxide. Their conductivity could not be measured owing to their insoluble nature. Fe complex with L2 showed loss of weight starting at $68^{\circ} \mathrm{C}(0.0012 \mathrm{gm})$ and decomposed at $305^{\circ} \mathrm{C}$ $(0.0057 \mathrm{gm})$ and complex with $\mathrm{L} 3$ at $66^{\circ} \mathrm{C}(0.0018 \mathrm{gm})$ and decomposed at $300^{\circ} \mathrm{C}(0.0055 \mathrm{gm})$ in the thermal analysis. Thus, confirming two molecules of water coordination in the complexes as per the composition predicted.

All the Fe(III) complexes formed with L1-L3 ligands have subnormal magnetic moments which may be due to the fact that metal-metal interactions or superexchange is anticipated $[76,78,79]$, as all the complexes may be binuclear in nature as shown in Table 16; Figure 5. The electronic spectra have very weak transitions and could not be concluded decisively and, however, are close to Oh symmetry with some tetragonal distortion.

3.5. Co Complexes. All Co(II) complexes are coloured, fine amorphous powders and decompose above $260^{\circ} \mathrm{C}$ without melting. They are all very stable to air, moisture and insoluble in most of the common organic solvents and to a small extent in 1-4 dioxane, dimethylformamide, and dimethyl sulfoxide. The conductivity of the compounds could not be determined owing to their insoluble nature. Co complex with $\mathrm{L} 1$ showed loss of weight starting at $52^{\circ} \mathrm{C}(0.0020 \mathrm{gm})$ and decomposed at $260^{\circ} \mathrm{C}(0.0555 \mathrm{gm})$ and complex with L3 at $54^{\circ} \mathrm{C}(0.0007 \mathrm{gm})$ and decomposed at $295^{\circ} \mathrm{C}(0.0089 \mathrm{gm})$ in the thermal analysis, thus confirming two molecules of water coordination in the complexes as per the composition predicted.

The observed magnetic moments of all the three Co(II) complexes formed with L1-L3 ligands are slightly lower than the expected 4.7-5.2 BM for high-spin octahedral $\mathrm{Co}$ (II) complexes as given in Table 17; Figure 6. The lower moments may be due to the metal-metal interactions [80].

In the Oh $\mathrm{Co}$ (II) complexes $4 \mathrm{Tlg}$ and $\mathrm{Eg}$ are the spinfree and spin-paired ground states. Broad band in lower energies and a multiple band in slightly higher energy in admixtures with spin-forbidden transition to doublet state are expected [72]. The asymmetric visible band is typical of Oh Co(II) complexes, the shoulder on the high energy side being assigned to spin-forbidden transitions [74].

3.6. Ni(II) Complexes. $\mathrm{Ni}(\mathrm{II})$ complexes are bright-red, green, and dark-brown in colour. These are insoluble in water and sparingly soluble in common organic solvents and also in 1-4 dioxane, dimethylformamide, and dimethyl sulfoxide. The conductivity could not be measured owing to very low solubility of the complexes. Ni complex with L1 at lower $\mathrm{pH}$ showed loss of weight starting at $68^{\circ} \mathrm{C}(0.0010 \mathrm{gm})$ and decomposed at $265^{\circ} \mathrm{C}(0.0053 \mathrm{gm})$ in the thermal analysis, thus confirming a molecule of water coordination in the complex as per the composition predicted.

The L1 complex at pH 5.5-7.0 and the L3 complexes are diamagnetic [81] and the other two with $\mathrm{L1}$ at $\mathrm{pH} 8.5$ and L2 have magnetic moment around 2.91-3.40 BM as expected for six-coordinated spin-free $\mathrm{Ni}(\mathrm{II})$ complexes as seen in Table 18; Figure 7. In regular $\mathrm{Oh}$ complexes of $\mathrm{Ni}$ (II) consideration of spin-orbit coupling and contribution from the $3 \mathrm{~A} 2 \mathrm{~g}$ and the next higher $3 \mathrm{~T} 2 \mathrm{~g}$ states give a somewhat higher magnetic moment than the spin-only moment of $2.83 \mathrm{BM}$ $[72,82,83]$.

The electronic spectra of the diamagnetic complex with L1 at $\mathrm{pH}$ 5.5-7.0 show two bands assigned to strong charge-transfer d-pi* transition [84] and the lower energy band to $1 \mathrm{~A} 1 \mathrm{~g} \rightarrow 1 \mathrm{~A} 2 \mathrm{~g}$ transition [74, 84-87] as expected for square-planar complexes. The other two complexes show three intense bands expected for regular octahedral geometry.

3.7. Cu(II) Complexes. All the complexes are coloured, fine amorphous powders and decompose above $250^{\circ} \mathrm{C}$ without melting. They are all very stable to air, moisture and are insoluble in most of the common organic solvents, except to a small extent in 1-4 dioxane, dimethylformamide, and dimethyl sulfoxide. The conductivity could not be measured 
TABLE 13: Electronic spectra and magnetic moment data for VO(II) complexes with L1-L6 ligands predicted molecular formula, structure, and geometry.

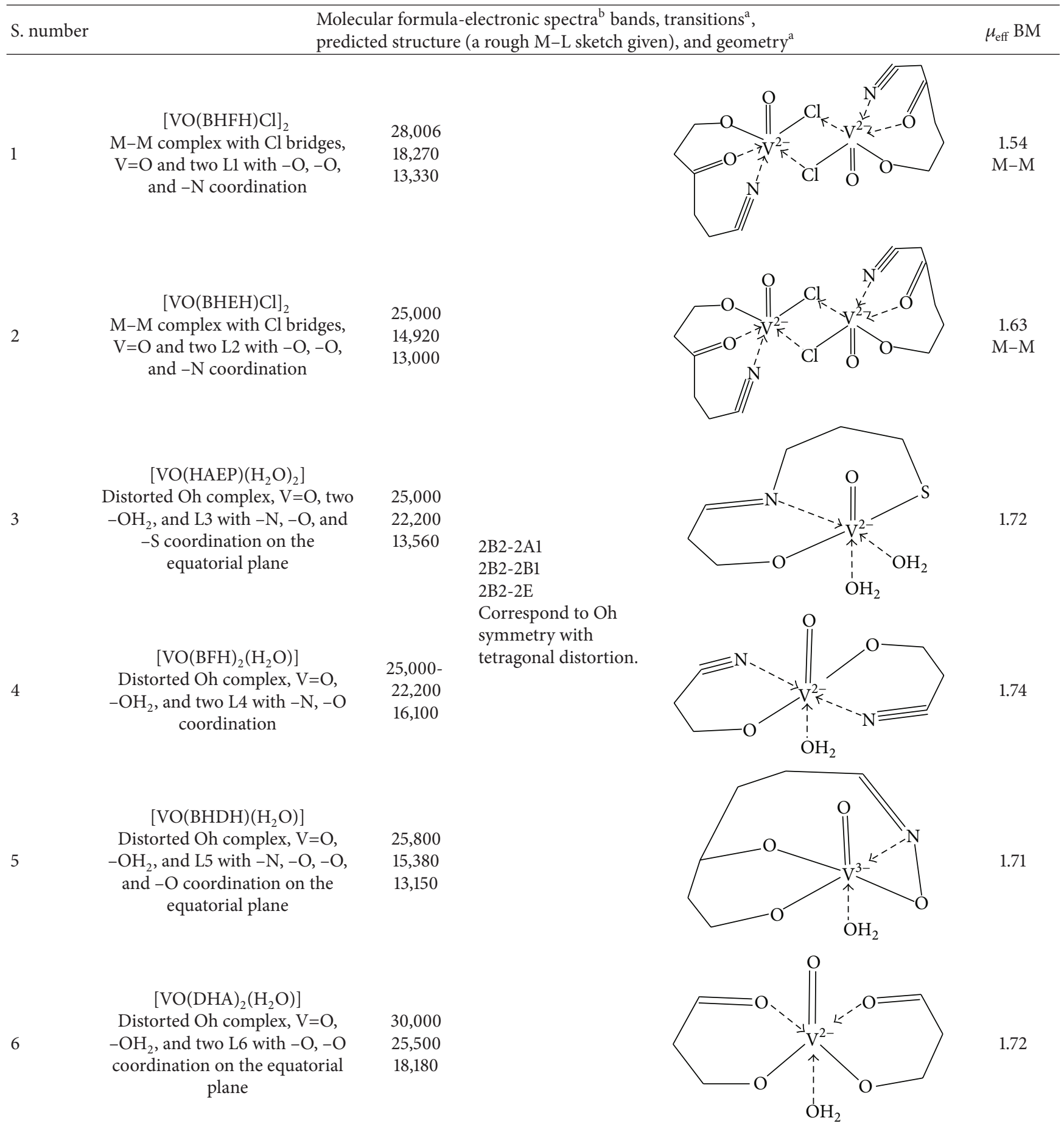

${ }^{a}$ Lever [73]; Rana et al. [104]; ${ }^{b}$ Recorded for solid compounds (mull-diffuse reflectance) at room temperature-Figures 1 and 2.

owing to their insoluble nature and their stoichiometry is deduced from the analytical data and geometry from the diffuse reflectance data in conjunction with magnetic moments. $\mathrm{Cu}$ complex with $\mathrm{L} 1$ at higher $\mathrm{pH}$ showed loss of weight starting at $73^{\circ} \mathrm{C}(0.0010 \mathrm{gm})$ and decomposed at $280^{\circ} \mathrm{C}(0.0300 \mathrm{gm})$ in the thermal analysis, thus confirming a molecule of water coordination in the complex as per the composition predicted.

The subnormal magnetic moments of $\mathrm{Cu} \mathrm{L1}$ at lower $\mathrm{pH}$ and Cu L3 indicate some metal-metal interactions in the solid 
TABLE 14: Predicted molecular formula, structure and geometry from electronic spectra and magnetic moment data for Cr(III) complexes with L3-L6 ligands.

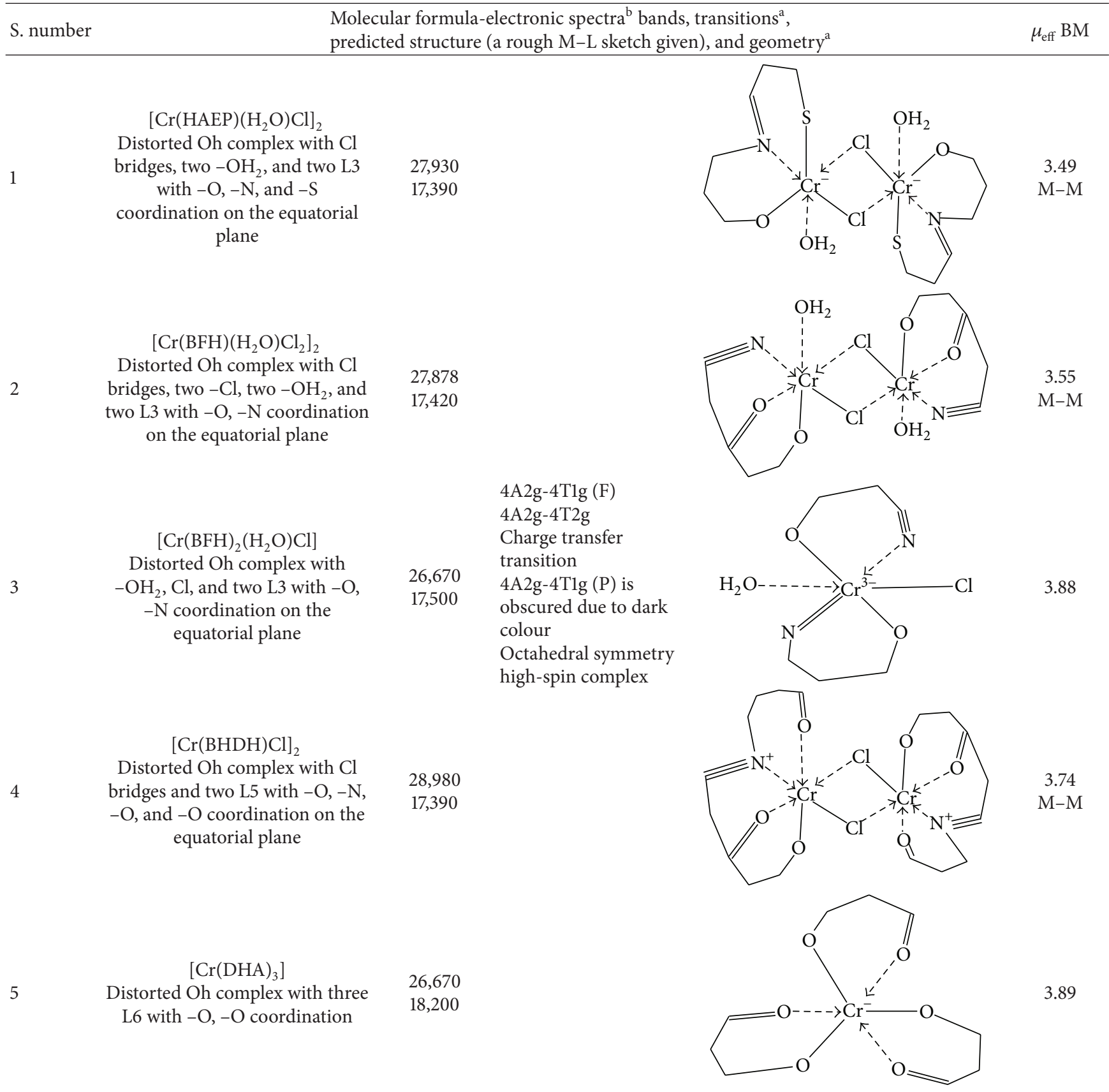

${ }^{a}$ Lever [73]; ${ }^{b}$ Recorded for solid compounds (mull-diffuse reflectance) at room temperature-Figure 3.

state. The dimeric nature of the complexes predicted with $\mathrm{O}$ and $-\mathrm{S}$ as bridges supports this $[88,89]$. All the data in the references cited show that magnetic moments of squareplanar $\mathrm{Cu}(\mathrm{II})$ complexes lie in the range of 1.7-1.9 BM. While slightly higher values of the other two complexes suggest presence of one unpaired electron with spin-orbit coupling [90]. Thus, all of the $\mathrm{Cu}(\mathrm{II})$ complexes are assigned [72] square-planar geometry as shown in Table 19; Figure 8. Two of them indicate metal-metal interactions due to slightly lower magnetic moments; one of them shows a loss of weight corresponding to one molecule of water from the TGA at variable temperature and one another with the chloride estimation.

3.8. Physiological Activity. The effect of the metal complex on fungal growth is measured by poisoning the nutrient (a solid like an agar-agar or a liquid medium) with a fungi toxicant. Then, it is allowed to grow as a test fungus. 
TABLE 15: Predicted molecular formula, structure, and geometry from electronic spectra and magnetic moment data for Mn(II) complexes with L1-L2 ligands.

Molecular formula-electronic spectra ${ }^{\mathrm{b}}$ bands, transitions ${ }^{\mathrm{a}}$,
predicted structure (a rough $\mathrm{M}-\mathrm{L}$ sketch given), and geometry

a Pappalardo [105]; b recorded for solid compounds (mull-diffuse reflectance) at room temperature-Figure 4.

TABLE 16: Predicted molecular formula, structure, and geometry from electronic spectra and magnetic moment data for Fe(III) complexes with L1-L3.

\begin{tabular}{|c|c|c|c|}
\hline S. number & $\begin{array}{l}\text { Molecular formula-el } \\
\text { predicted structure (a }\end{array}$ & $\begin{array}{l}\text { ctronic spectra }^{\mathrm{b}} \text { bands, transitions } \mathrm{s}^{\mathrm{a}} \\
\text { ough } \mathrm{M}-\mathrm{L} \text { sketch given), and geometry }\end{array}$ & $\mu_{\mathrm{eff}} \mathrm{BM}$ \\
\hline 1 & $\begin{array}{c}{\left[\mathrm{Fe}(\mathrm{BHFH}) \mathrm{Cl}_{2}\right]_{2}} \\
\text { Distorted Oh complex with } \mathrm{Cl} \text { bridges, two }-\mathrm{Cl} \text {, } \\
\text { and two } \mathrm{L} 1 \text { with }-\mathrm{O},-\mathrm{O} \text {, and }-\mathrm{N} \text { coordination on } \\
\text { the equatorial plane }\end{array}$ & $\begin{array}{l}23,260 \\
21,740 \\
19,040 \\
17,540\end{array}$ & $\begin{array}{c}5.70 \\
\mathrm{M}-\mathrm{M}\end{array}$ \\
\hline 2 & $\begin{array}{l}{\left[\mathrm{Fe}(\mathrm{BHEH})\left(\mathrm{H}_{2} \mathrm{O}\right) \mathrm{Cl}\right]_{2}} \\
\text { Distorted } \mathrm{Oh} \text { complex with } \mathrm{Cl} \text { bridges, two } \\
-\mathrm{OH}_{2} \text {, and two } \mathrm{L} 2 \text { with }-\mathrm{O},-\mathrm{O} \text {, and }-\mathrm{N} \\
\text { coordination on the equatorial plane }\end{array}$ & $\begin{array}{l}26,670 \\
22,220 \\
18,520 \\
17,390 \\
15,600\end{array}$ & $\begin{array}{l}5.73 \\
\mathrm{M}-\mathrm{M}\end{array}$ \\
\hline 3 & $\begin{array}{l}\left.\qquad \mathrm{Fe}(\mathrm{HAEP})\left(\mathrm{H}_{2} \mathrm{O}\right) \mathrm{Cl}\right]_{2} \\
\text { Distorted Oh complex with } \mathrm{S} \text { bridges, two }-\mathrm{OH}_{2} \text {, } \\
\text { two }-\mathrm{Cl} \text {, and two } \mathrm{L} 3 \text { with }-\mathrm{O},-\mathrm{N} \text {, and }-\mathrm{S} \text { (used in } \\
\text { bridging) coordination on the equatorial plane }\end{array}$ & $\begin{array}{l}\text { Extremely } \\
\quad \text { weak } \\
\text { transitions }\end{array}$ & $\begin{array}{c}5.88 \\
\mathrm{M}-\mathrm{M}\end{array}$ \\
\hline
\end{tabular}

${ }^{\mathrm{a}}$ Oh geometry with metal-metal interactions; ${ }^{\mathrm{b}}$ Recorded for solid compounds (mull-diffuse reflectance) at room temperature-Figure 5.

\subsection{For the Organism Rhizoctonia Solani}

(i) L1 has shown $30 \%$ inhibition at $1000 \mathrm{ppm}, 17 \%$ at $500 \mathrm{ppm}$, and nil effect at $250 \mathrm{ppm}$ (Table 20). Hence, all the newly synthesized complexes were tested for activity at $1000 \mathrm{ppm}$ (observe carefully Figure 9). It was found that the $\mathrm{VO}$ (II) complex is $100 \%$ effective,
Mn(II) 95\%, Fe(III) 62\%, Co(II) nil effect, Ni(II) 45\% and $\mathrm{Cu}(\mathrm{II})$ nil effect. Thus, the activity order may be evaluated as $\mathrm{VO}>\mathrm{Mn}>\mathrm{Fe}>\mathrm{Ni}>\mathrm{L1}>\mathrm{Co}=\mathrm{Cu}$.

(ii) L2 shows the following trend $\mathrm{VO}>\mathrm{Mn}>\mathrm{Ni}>\mathrm{Cu}>$ L2 > Co. 
TABLE 17: Predicted molecular formula, structure, and geometry from electronic spectra and magnetic moment data for Co(II) complexes with L1-L3 ligands.

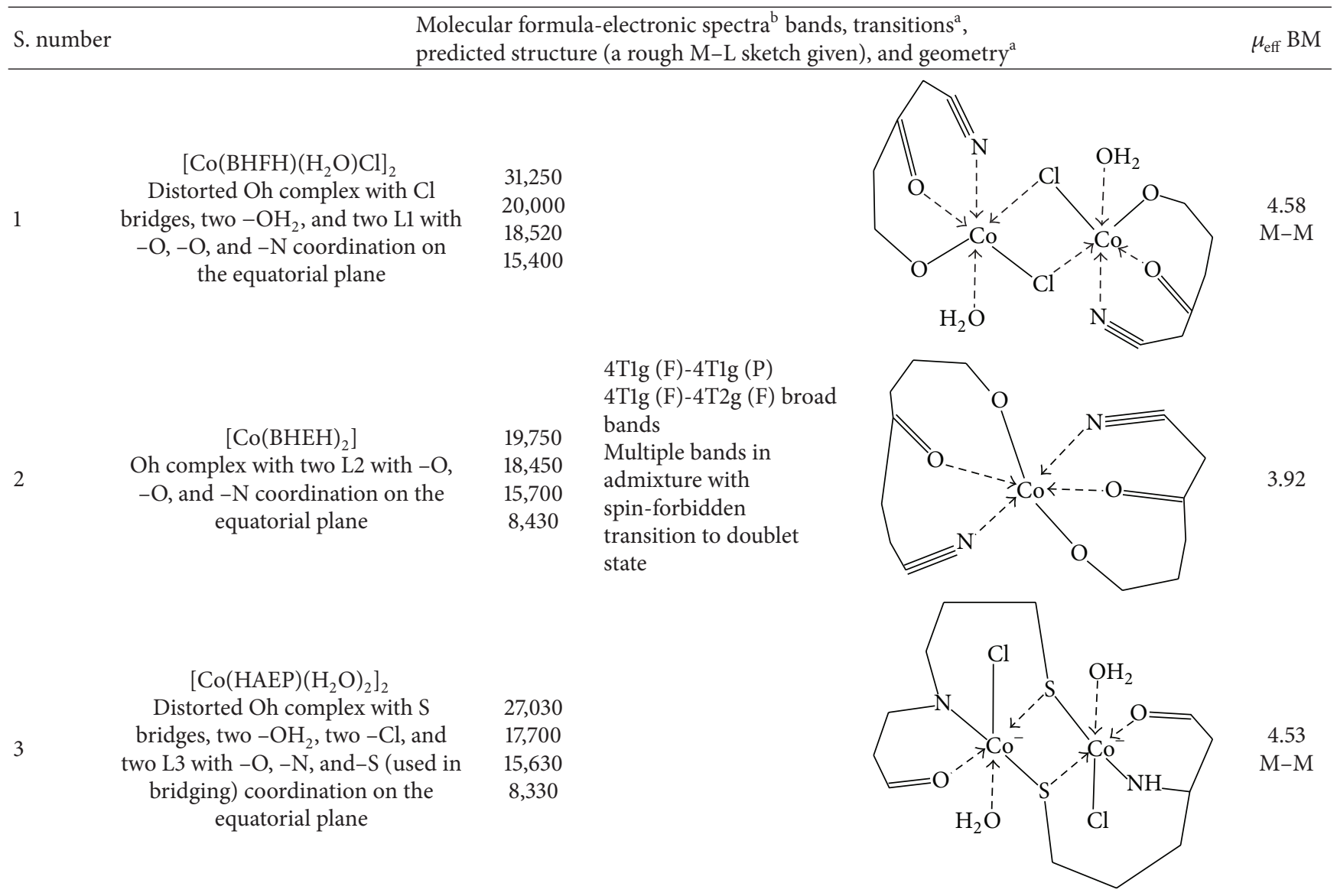

${ }^{a}$ Lever [73]; the asymmetric visible band is typical of $\mathrm{Oh} \mathrm{Co}(\mathrm{II})$ complexes and the shoulder on the high energy side being assigned to spin-forbidden transitions, Drago [74]; ${ }^{b}$ Recorded for solid compounds (mull-diffuse reflectance) at room temperature-Figure 6.

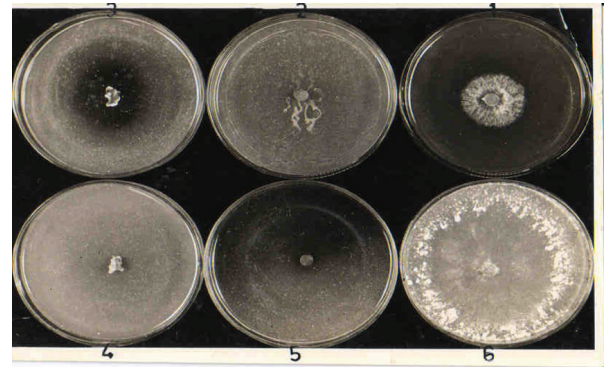

FIgURE 9: Activity observed for the following: 1-Dithane M45$500 \mathrm{ppm} ; 2-\mathrm{VO}(\mathrm{II})-250 \mathrm{ppm} ; 3-\mathrm{VO}(\mathrm{II})-500 \mathrm{ppm} ; 4-\mathrm{VO}(\mathrm{II})-$ 750 ppm; 5-VO(II)-1000 ppm and 6-Blank.

(iii) quite unexpectedly, L3 upon complexation completely subsides the activity. This may be due to the presence of two free -OH groups and one free $\mathrm{NH}_{2}$ group in the ligand, the structure of which is comparable to the antidotes used for the expulsion of food poisoning in hospitals.

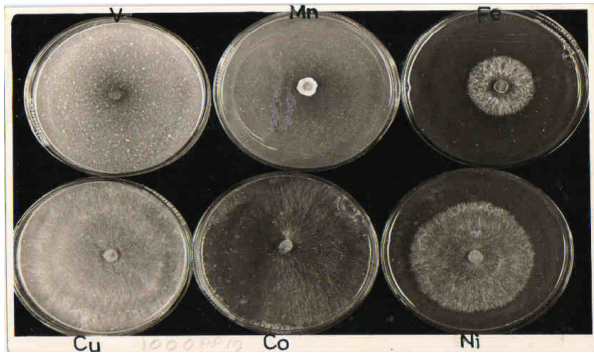

Figure 10: Complexes with VO(II)-100\% effective, Mn(II)-95\% effective, $\mathrm{Fe}(\mathrm{III})-62 \%$ effective, $\mathrm{Ni}(\mathrm{II})-45 \%$ effective, and $\mathrm{Co}(\mathrm{II})$, $\mathrm{Cu}(\mathrm{II})$-nil effect are observed in this photo.

(iv) L4 trend shows $\mathrm{VO}>\mathrm{Cr}>\mathrm{L} 4$.

(v) L5, L6 show VO > Cr.

Thus the complexes with L1, L2, and L4 are as effective as the commercially used Dithane M-45 (Table 20). The VO complexes with $\mathrm{L} 1$ and $\mathrm{L} 2$ are dimeric in nature and probably in solution dissociate to monomeric units due to the $\mathrm{V}=\mathrm{O}$ 
TABle 18: Predicted molecular formula, structure, and geometry from electronic spectra and magnetic moment data for Ni(II) complexes with L1-L3 ligands.

\begin{tabular}{|c|c|c|c|c|}
\hline S. number & $\begin{array}{l}\text { Molec } \\
\text { predic }\end{array}$ & $\begin{array}{l}\text { ular formula } \\
\text { ted structure }\end{array}$ & $\begin{array}{l}\text {-electronic spectra }{ }^{\mathrm{b}} \text { bands, transitions }{ }^{\mathrm{a}} \text {, } \\
\text { (a rough M-L sketch given), and geometry }\end{array}$ & $\mu_{\mathrm{eff}} \mathrm{BM}$ \\
\hline 1 & $\begin{array}{c}{\left[\mathrm{Ni}(\mathrm{BHFH}) \mathrm{H}_{2} \mathrm{O}\right]} \\
\text { Square-planar complex with }-\mathrm{OH}_{2} \\
\text { and } \mathrm{Ll} \text { with }-\mathrm{O},-\mathrm{O} \text {, and }-\mathrm{N} \\
\text { coordination on the equatorial } \\
\text { plane }\end{array}$ & $\begin{array}{l}26,130 \\
18,100\end{array}$ & $\begin{array}{l}\text { Charge-transfer band d-pi* } \\
\text { transition } \\
1 \mathrm{~A} 1 \mathrm{~g} \cdot 1 \mathrm{~A} 2 \mathrm{~g} \\
\text { Square-planar geometry }\end{array}$ & Dia \\
\hline 2 & $\begin{array}{c}{\left[\mathrm{Ni}(\mathrm{BHFH})_{2}\right]} \\
\text { Regular Oh complex with two L1 } \\
\text { with }-\mathrm{O},-\mathrm{O} \text {, and }-\mathrm{N} \text { coordination }\end{array}$ & $\begin{array}{c}26,300 \\
15,000 \\
9,520(w)\end{array}$ & $\begin{array}{c}\text { 3A2g-3Tlg }(\mathrm{P}) \\
\text { 3A2g-3T1g }(\mathrm{G}) \\
\text { 3A2g-3T2g } \\
\text { Regular Oh geometry }\end{array}$ & 3.24 \\
\hline 3 & $\begin{array}{c}{\left[\mathrm{Ni}(\mathrm{BHEH})_{2}\right]} \\
\text { Regular Oh complex with two L1 } \\
\text { with }-\mathrm{O},-\mathrm{O} \text {, and }-\mathrm{N} \text { coordination }\end{array}$ & $\begin{array}{l}26,670(\mathrm{~s}) \\
20,000 \\
13,100 \\
8,200(\mathrm{w})\end{array}$ & $\begin{array}{l}\text { Strong charge-transfer } \\
\text { band-d-pi* transition } \\
\text { 3A2g-3T1g }(\mathrm{P}) \\
\text { 3A2g-2T1g, 3T1g (F) } \\
\text { 3A2g-3T2g } \\
\text { Regular Oh geometry }\end{array}$ & 2.91 \\
\hline 4 & $\begin{array}{c}{\left[\mathrm{Ni}(\mathrm{HAEP})_{2}\right]} \\
\text { Distorted square-planar complex } \\
\text { with } \mathrm{S} \text { bridges and two L3 with }-\mathrm{O} \text {, } \\
-\mathrm{N},-\mathrm{S} \text { (used in bridging) } \\
\text { coordination on the equatorial } \\
\text { plane }\end{array}$ & $\begin{array}{l}27,030 \\
16,600\end{array}$ & $\begin{array}{c}\text { Charge-transfer band d-pi* } \\
\text { transition } \\
\text { 1A1g-1A2g } \\
\text { Diamagnetic tetragonal or } \\
\text { square planar complex with } \\
\text { high intensity band in } \\
14000-18000 \mathrm{~cm}^{-1}\end{array}$ & $\begin{array}{l}\text { Dia } \\
\mathrm{M}-\mathrm{M}\end{array}$ \\
\hline
\end{tabular}

${ }^{\mathrm{a}}$ Holm et al. [77]; Shaw and Dudek [106]; Drago [74]; ${ }^{\mathrm{b}}$ Recorded for solid compounds (mull-diffuse reflectance) at room temperature-Figure 7.

group unlike the other dimeric complexes synthesized. The $-\mathrm{O}$ of $\mathrm{V}=\mathrm{O}$ might bind in such a way that the activity order is tremendously increased and the growth of fungus is completely inhibited making it $100 \%$ effective. And probably the ligands are bound to metal atoms by rearrangement caused by enolization, thus making them more viable for dissociation, unlike the first deceptive appearance they give as if they are coordinately more saturated.

In the Case of Acrocylindrium oryzae, a nominal activity for the L4-L6 Cr(III) complexes and maximum activity for all $\mathrm{VO}$ (II) complexes were observed. Hence, screening of $\mathrm{VO}$ (II) complex of L1 was done at lower concentrations and compared with the commercially used fungicide Dithane M-45 (observe carefully Figure 10). From the average of four replications in each case, the dry-weight of the fungal mycelium was recorded in milligrams and was shown in Table 20. It was observed that L1-L3 has totally inhibited the growth at 1000, 500, and $250 \mathrm{ppm}$. Nominal growth of the organism on the disc of the inoculums was observed to be about $2-5 \mathrm{mg}$. but L4 showed nominal activity at 1000 ppm with decreased activity at lower concentrations. So the activity order for all these is given as follows. $\mathrm{L1}>\mathrm{VO}>$ $\mathrm{Ni}>\mathrm{Mn}>\mathrm{Fe}>\mathrm{Co}>\mathrm{Cu}$ and $\mathrm{L} 2>\mathrm{Ni}>\mathrm{VO}>\mathrm{Mn}>\mathrm{Fe}>$ $\mathrm{Cu}>\mathrm{Co}$. Cr(III) complexes of L3-L6 were found less toxic than VO(II) complexes. The activity of these was found to be marginal when compared to that of the commercial Dithane $\mathrm{M}-45$. Interestingly, it was found that the $\mathrm{VO}$ (II) complex at $250 \mathrm{ppm}$ is more effective compared to Dithane M-45 at $500 \mathrm{ppm}$ and may be more useful. It is interesting to note from the above data that L1 and L2 are very toxic to this organism 
TABLE 19: Predicted molecular formula, structure, and geometry from electronic and magnetic moment data for Cu(II) complexes with L1-L3 ligands.

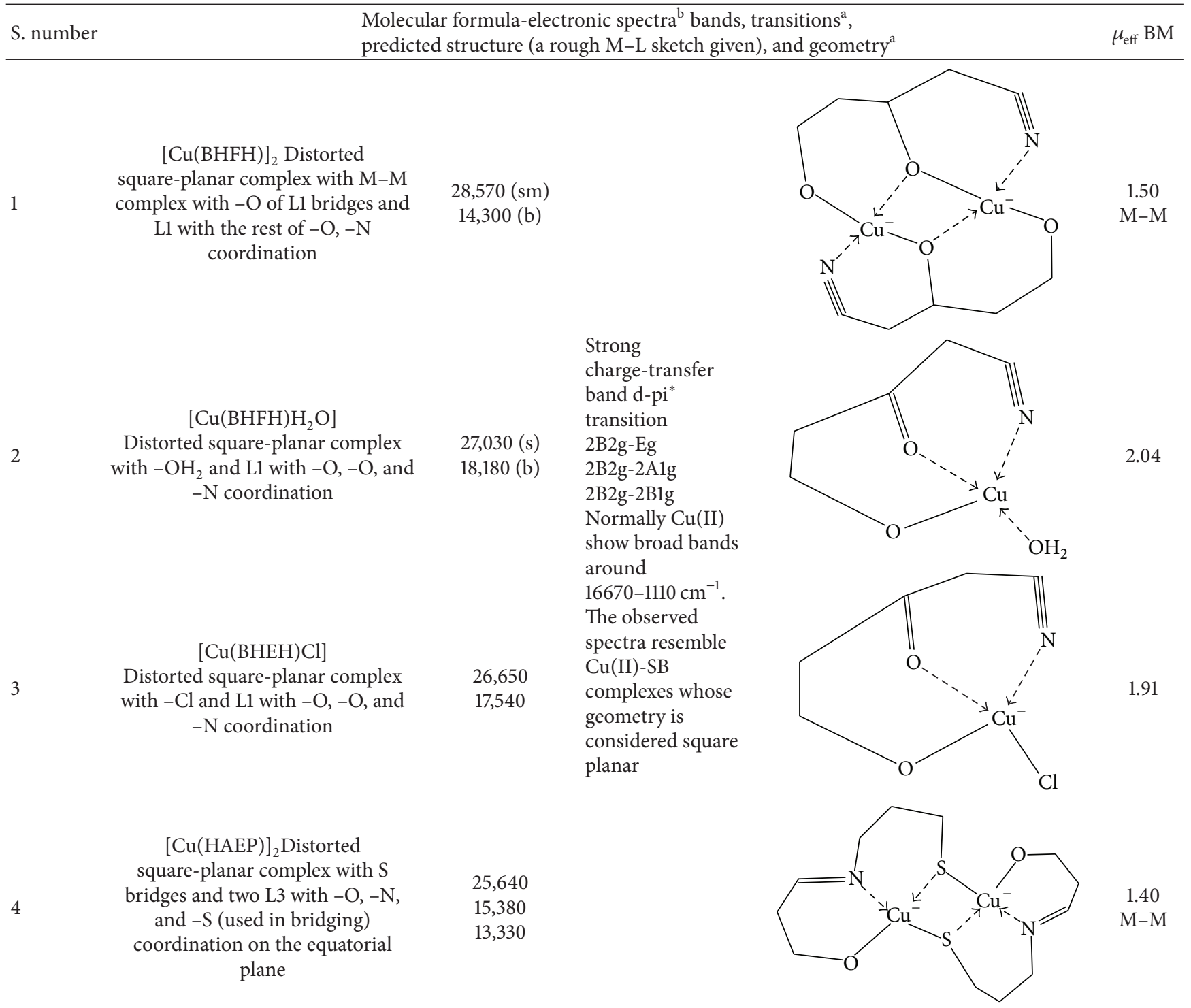

${ }^{a}$ Lever [73]; Sutton [107]; Satyanarayana and Mohapathra [108]; Sacconi and Ciampolini [109]; Muzundar and Bhattacharya [110]; Sheela [111]; ${ }^{\mathrm{b}}$ Recorded for solid compounds (mull-diffuse reflectance) at room temperature-Figure 8.

compared to Rhizoctonia solani and also VO(II) complexes show more activity.

After 48 hrs of inoculation of the bacterium Xanthomonas oryzae, percentage inhibition growth was calculated from each plate and average readings from fine replicas are shown in Table 20. It was observed that neither the ligands nor the complexes could control the growth of this bacterium fully. None of the complexes showed considerable percentage inhibition at the $1000 \mathrm{ppm}$ concentration and, hence, they were not screened at lower concentrations. The saturated bactericide, Branidiol, was also found to be effective only to the extent of $50 \%$ but its effect so persists in the system that the growth is arrested at that stage and never continues. The order of activity of complexes of $\mathrm{L} 1$ is as follows: $\mathrm{VO}>\mathrm{Mn}>$ $\mathrm{Fe}>\mathrm{L} 1>\mathrm{Ni}>\mathrm{Co}>\mathrm{Cu}$ and that in the complexes of $\mathrm{L} 2$ is $\mathrm{Ni}$
$>\mathrm{Mn}>\mathrm{VO}>\mathrm{Co}>\mathrm{Fe}>\mathrm{Cu}>\mathrm{L} 2 . \mathrm{L} 3$ and all its complexes have shown nil activity on this bacterium. L4-L6 and their $\mathrm{Cr}(\mathrm{III}), \mathrm{VO}$ (II) complexes were screened and the order of activity in them was as follows: $\mathrm{VO}>\mathrm{Cr}>\mathrm{L} 4>\mathrm{L} 5>\mathrm{L} 6$. Thus it was observed that the complexation increases the activity of ligand, but it was less than the standard bactericide, Bronidiol.

\section{Conclusions}

Synthesis of Schiff bases L1-L5 and L6 and their use as ligands for coordination with $\mathrm{VO}(\mathrm{II}), \mathrm{Cr}$ (III), $\mathrm{Mn}$ (II), Fe(III), $\mathrm{Co}(\mathrm{II}), \mathrm{Ni}(\mathrm{II})$, and $\mathrm{Cu}(\mathrm{II})$ form a major study. All the prepared complexes were analyzed by $\mathrm{C}, \mathrm{H}, \mathrm{N}, \mathrm{Cl}$, and metal analyses. They were assigned molecular structures and geometries using information obtained from IR, UV-Vis, 
TABLE 20: Evaluation of fungicidal property of Schiff bases and metal complexes in vitro.

\begin{tabular}{|c|c|c|c|c|c|c|c|c|c|c|}
\hline \multirow[t]{2}{*}{ S. number } & \multirow[t]{2}{*}{$\begin{array}{l}\text { Chemical } \\
\text { complex }\end{array}$} & \multicolumn{3}{|c|}{$\begin{array}{l}\text { Rhizoctonia solani (PDA } \\
\text { medium), average } \% \\
\text { nhibition of growth after } 72 \mathrm{hrs;} \\
\text { poisoned food technique } \\
\text { concentration in ppm }\end{array}$} & \multicolumn{3}{|c|}{$\begin{array}{c}\text { Acrocylindrium oryzae (PA } \\
\text { liquid) average } \% \\
\text { inhibition of growth after } 48 \mathrm{hrs} ; \\
\text { liquid broth method } \\
\text { concentration in ppm }\end{array}$} & \multicolumn{3}{|c|}{$\begin{array}{c}\text { Xanthomonas oryzae (Hayward's } \\
\text { medium) average \% } \\
\text { inhibition of growth after } 8 \text { days; } \\
\text { inhibition zone technique } \\
\text { concentration in ppm }\end{array}$} \\
\hline & & 1000 & 500 & 250 & 1000 & 500 & 250 & 1000 & 500 & 250 \\
\hline 1 & BLANK & - & - & - & 246 & 245 & 246 & - & - & - \\
\hline 2 & DITHANE-M-45 & 100 & 100 & 80 & nil & 200 & 240 & 55 & 50 & 48 \\
\hline 3 & L1-BHFH & 30 & 16.66 & - & nil & nil & 2 & 12 & -- & -- \\
\hline 4 & {$[\mathrm{Cu}(\mathrm{BHFH})]_{2}$} & - & -- & -- & 190 & 200 & 240 & 5 & -- & -- \\
\hline 5 & {$\left[\mathrm{Co}(\mathrm{BHFH})\left(\mathrm{H}_{2} \mathrm{O}\right) \mathrm{Cl}\right]_{2}$} & - & -- & -- & 170 & 150 & 240 & 8 & -- & -- \\
\hline 6 & {$[\mathrm{Ni}(\mathrm{BHFH})]_{2}$} & 45.5 & 15 & - & 5 & 28 & 130 & 11.2 & -- & -- \\
\hline 7 & {$\left[\mathrm{Fe}(\mathrm{BHFH}) \mathrm{Cl}_{2}\right]_{2}$} & 62.2 & 34.4 & 10 & 55 & 100 & 220 & 22.3 & -- & -- \\
\hline 8 & {$\left[\mathrm{Mn}(\mathrm{BHFH})\left(\mathrm{H}_{2} \mathrm{O}\right) \mathrm{Cl}\right]_{2}$} & 295.2 & 67.2 & 40 & 25 & 76 & 130 & 23 & -- & -- \\
\hline 9 & {$[\mathrm{VO}(\mathrm{BHFH}) \mathrm{Cl}]_{2}$} & 100 & 69.66 & 50 & nil & nil & 12 & 20 & -- & -- \\
\hline 10 & L2-BHEH & 20 & 6.6 & - & nil & nil & 2 & 3 & -- & -- \\
\hline 11 & {$[\mathrm{Cu}(\mathrm{BHEH}) \mathrm{Cl}]$} & 25 & 21.1 & 10 & 150 & 200 & 245 & 8 & -- & -- \\
\hline 12 & {$\left[\mathrm{Co}(\mathrm{BHEH})_{2}\right]$} & - & -- & -- & 175 & 190 & 225 & 16.7 & -- & -- \\
\hline 13 & {$\left[\mathrm{Ni}(\mathrm{BHEH})_{2}\right]$} & 27 & -- & -- & nil & nil & nil & 30 & -- & -- \\
\hline 14 & $\left.\left[\mathrm{Fe}(\mathrm{BHEH})\left(\mathrm{H}_{2} \mathrm{O}\right) \mathrm{Cl}\right)\right]_{2}$ & 35 & 20 & - & 100 & 155 & 200 & 15 & -- & -- \\
\hline 15 & {$\left[\mathrm{Mn}(\mathrm{BHEH})_{2}\right]$} & 82 & 50 & 50 & 96 & 100 & 150 & 19 & -- & -- \\
\hline 16 & {$[\mathrm{VO}(\mathrm{BHEH}) \mathrm{Cl}]_{2}$} & 100 & 45 & 40 & nil & nil & 50 & 20 & -- & -- \\
\hline 17 & L3-HAEP & 50 & 20 & - & 5 & 5 & 5 & 10 & -- & -- \\
\hline 18 & {$[\mathrm{Cu}(\mathrm{HAEP})]_{2}$} & - & -- & -- & 245 & -- & -- & -- & -- & -- \\
\hline 19 & {$\left[\mathrm{Co}(\mathrm{HAEP})\left(\mathrm{H}_{2} \mathrm{O}\right)_{2}\right]_{2}$} & - & -- & -- & 240 & -- & -- & -- & -- & -- \\
\hline 20 & {$\left[\mathrm{Ni}(\mathrm{HAEP})_{2}\right]$} & - & -- & -- & 185 & -- & -- & -- & -- & -- \\
\hline 21 & {$\left[\mathrm{Fe}(\mathrm{HAEP})\left(\mathrm{H}_{2} \mathrm{O}\right) \mathrm{Cl}\right]_{2}$} & - & -- & -- & 200 & -- & -- & -- & -- & -- \\
\hline 22 & {$\left[\mathrm{Cr}(\mathrm{HAEP})\left(\mathrm{H}_{2} \mathrm{O}\right) \mathrm{Cl}\right]_{2}$} & - & -- & -- & 242 & -- & -- & -- & -- & -- \\
\hline 23 & {$\left[\mathrm{VO}(\mathrm{HAEP})\left(\mathrm{H}_{2} \mathrm{O}\right)_{2}\right]$} & - & -- & -- & 245 & -- & -- & 2 & -- & -- \\
\hline 24 & L4-BFH & 32 & 20 & - & 70 & 100 & 240 & 20 & -- & -- \\
\hline 25 & {$\left[\mathrm{Cr}(\mathrm{BFH})\left(\mathrm{H}_{2} \mathrm{O}\right) \mathrm{Cl}_{2}\right]_{2}$} & - & -- & -- & 150 & 200 & 240 & 22 & -- & -- \\
\hline 26 & {$\left[\mathrm{VO}(\mathrm{BFH})_{2}\left(\mathrm{H}_{2} \mathrm{O}\right)\right]$} & 98 & 69.66 & 50 & 125 & 150 & 200 & 25 & -- & -- \\
\hline 27 & {$[\mathrm{Cr}(\mathrm{BHDH}) \mathrm{Cl}]_{2}$} & 15.5 & 5.12 & 5 & 190 & -- & -- & 15 & -- & -- \\
\hline 28 & {$\left[\mathrm{VO}(\mathrm{BHDH})\left(\mathrm{H}_{2} \mathrm{O}\right)\right]$} & 32.2 & 15 & - & 150 & 198 & 240 & 20 & -- & -- \\
\hline 29 & {$\left[\mathrm{Cr}(\mathrm{DHA})_{3}\right]$} & 28.5 & -- & -- & 200 & 240 & 245 & 15 & -- & -- \\
\hline 30 & {$\left[\mathrm{VO}(\mathrm{DHA})_{2}\left(\mathrm{H}_{2} \mathrm{O}\right)\right]$} & 50 & 30 & 15 & 170 & 200 & 238 & 18 & -- & -- \\
\hline
\end{tabular}

- indicates negative effect; - - indicates that the compound is not screened.

magnetic susceptibility, and TGA analysis. The physiological activity studies with ligands L1-L4 along with some results of metal complexes with L1-L6 ligands are tabulated, suggesting them to be toxic to the organisms studied and, hence, may be useful as fungicides and bactericides. The VO(II) complexes are found to be more active compared to the activity of the commercial standard.

\section{Conflict of Interests}

The authors declare that there is no conflict of interests regarding the publication of this paper.

\section{Acknowledgment}

The author, T. Mangamamba, would like to thank All India Coordinated Rice Improvement Project (ACRIP), Rajendranagar, Hyderabad, for allowing her to use their facility for the study of physiological activity.

\section{References}

[1] S. Patai, "The chemistry of carbon-nitrogen double bond," in General and Theoretical Aspects, C. Sandorfy, Ed., chapter 1, pp. 1-60, Interscience, William Clowes and Sons, London, UK, 1970.

[2] F. P. Dwyer and D. P. Mellor, Chelating Agents and Metal Chelates, Academic Press, New York, NY, USA, 1964.

[3] H. Holm, G. W. Everett, and A. Chakraborty, "Metal complexes of Schiff bases and $\beta$-ketoamines," Progress in Inorganic Chemistry, vol. 7, pp. 83-214, 1966.

[4] J. W. Smith, The Chemistry of Carbon-Nitrogen Double Bond, edited by S. Patai, International Science Publishing, London, UK, 1970.

[5] L. F. Lindoy, "Metal-ion control in the synthesis of Schiff base complexes," Quarterly Reviews, Chemical Society, vol. 25, no. 3, pp. 379-391, 1971.

[6] B. O. West, E. A. V. Ebsworth, A. G. Maddock, and A. G. Sharp, New Pathways in Inorganic Chemistry, Cambridge University Press, London, UK, 1966. 
[7] S. Yamada, "Recent aspects of the stereochemistry of Schiffbase-metal complexes," Coordination Chemistry Reviews, vol. 1, 4, pp. 415-437, 1966.

[8] M. J. Norgett, J. H. M. Thornley, and L. M. Venanzi, “The visible and ultraviolet spectra of $\mathrm{d}^{6}-, \mathrm{d}^{7}-$ and $\mathrm{d}^{8}$-metal ions in trigonal bipyramidal complexes," Coordination Chemistry Reviews, vol. 2, no. 1, pp. 83-98, 1967.

[9] N. F. Curtis, "Macrocyclic coordination compounds formed by condensation of metal-amine complexes with aliphatic carbonyl compounds," Coordination Chemistry Reviews, vol. 3, no. 1, pp. 3-47, 1968.

[10] E. Bayer, "Structure and specificity of organic chelating agents," Angewandte Chemie International Edition, vol. 3, no. 5, pp. 325332, 1964.

[11] E. Jungreis and S. Thabet, "Analytical application of schiff bases," in Chelates in Analytical Chemistry, H. A. Flaschka and A. J. Barnard Jr., Eds., vol. 2, pp. 149-177, Marcel Dekker, New York, NY, USA, 1969.

[12] F. Feigl, Spot Tests in Organic Analysis, vol. 2, Elsevier, New York, NY, USA, 1958.

[13] J. C. Bailar, Chemistry of Coordination Compounds, Reinhold, 1956.

[14] A. E. Martell and M. Calwin, Chemistry of Metal Chelate Compounds, Prentice-Hall, Upper Saddle River, NJ, USA, 1952.

[15] S. Chaberek and A. Martell, Sequestering Agents, John Wiley \& Sons, New York, NY, USA, 1959.

[16] R. L. Smith, The Sequesteration of Metals: Theoretical Considerations and Practical Applications, Chapman \& Hall, London, UK, 1959.

[17] E. R. Inman and I. A. Macpherson, ChemicalAbstracts, vol. 74, Article ID 77398, 1971.

[18] C. S. Marvell and N. Tarkoy, "Heat stability studies on chelates from schiff bases of salicylaldehyde derivatives. II," Journal of the American Chemical Society, vol. 80, no. 4, pp. 832-835, 1958.

[19] W. Qin, S. Long, M. Panunzio, and B. Stefano, "Schiff bases: a short survey on an evergreen chemistry tool," Molecules, vol. 18, no. 10, pp. 12264-12289, 2013.

[20] S. Kumar, D. N. Dhar, and P. N. Saxena, "Applications of metal complexes of Schiff bases-a review," Journal of Scientific and Industrial Research, vol. 68, no. 3, pp. 181-187, 2009.

[21] R. Katwal, H. Kaura, and B. K. Kapur, "Applications of copperSchiff's base complexes: a review," Scientific Reviews \& Chemical Communications, vol. 3, no. 1, pp. 1-15, 2013.

[22] R. K. Parashar, R. C. Sharma, and G. Mohan, "Biological activity of some Schiff bases and their metal complexes," Biological Trace Element Research, vol. 23, pp. 145-150, 1990.

[23] S. Pattanaik, S. S. Rout, J. Panda, P. K. Sahu, and M. Banerjee, "Synthesis, characterisation and biological evaluation of bedentate ligands (Reduced Schiff's Base) with metals of copper, nickel and zinc complexes," Rasayan Journal of Chemistry, vol. 4, no. 1, pp. 136-141, 2011.

[24] S. Malik, S. Ghosh, and L. Mitu, "Complexes of some 3d-metals with a Schiff base derived from 5-acetamido-1,3,4-thiadiazole2-sulphonamide and their biological activity," Journal of the Serbian Chemical Society, vol. 76, no. 10, pp. 1387-1394, 2011.

[25] K. Krishnankutty, M. B. Ummathur, and P. Sayudevi, "Metal complexes of schiff bases derived from dicinnamoylmethane and aromatic amines," The Journal of the Argentine Chemical Society, vol. 96, no. 1-2, pp. 13-21, 2008.
[26] P. Subramanian and M. Sakunthala, "Antibacterial activities of new Schiff base metal complexes synthesised from 2-hydroxy1-naphthaldehyde and 5-amino-1-naphthol," World Journal of Pharmacy and Pharmaceutical Sciences, vol. 2, no. 5, pp. 27532764, 2013.

[27] B. Lakshmi, K. N. Shivananda, G. A. Prakash, A. M. Isloor, and K. N. Mahendra, "Synthesis and characterization of schiff base metal complexes and reactivity studies with malemide epoxy resin," Bulletin of the Korean Chemical Society, vol. 33, no. 2, pp. 473-482, 2012.

[28] G. Puthilibai, Synthesis, spectral, electrochemical, antibacterial and DNA binding properties of $\mathrm{Cu}(\mathrm{II}), \mathrm{Ni}(\mathrm{II})$ and $\mathrm{Co}(\mathrm{II})$ Schiff bases complexes derived from 2- $\mathrm{H} / \mathrm{Cl} / \mathrm{Br}-4-\mathrm{H} / \mathrm{Cl}-6-(4-$ fluorophenlyiminomethyl)phenol [Ph.D. thesis], 2010.

[29] A. Sharma, T. Mehta, and M. K. Shah, "Synthesis and spectral studies of transition metal complexes supported by NO- bidentate Schiff-Base ligand," Pelagia Research Library: Der Chemica Sinica, vol. 4, no. 1, pp. 141-146, 2013.

[30] M. B. Halli, R. S. Malipatil, R. B. Sumathi, and K. Shivakumar, "Synthesis, spectroscopic characterization and biological activity studies of Schiff base metal complexes derived from $\mathrm{N}^{\prime}$-(4(methylthio) benzylidene)benzofuran-2-carbo hydrazide," Der Pharmacia Lettre, vol. 5, no. 4, pp. 182-188, 2013.

[31] N. Akbolat, A. Yıldız, H. Temel, S. Ilhan, and G. Gul, "Antifungal studies of some metal complexes with Schiff base ligands," DUFED, vol. 1, no. 1, pp. 15-22, 2012.

[32] G. G. Mohamed, M. M. Omar, and A. M. Hindy, "Metal complexes of Schiff bases: preparation, characterization, and biological activity," Turkish Journal of Chemistry, vol. 30, no. 3, pp. 361-382, 2006.

[33] E. Yousif, A. Majeed, K. Al-Sammarrae, N. Salih, J. Salimon, and B. Abdullah, "Metal complexes of Schiff base: preparation, characterization and antibacterial activity," Arabian Journal of Chemistry, 2013.

[34] V. Arun and K. K. Mohammed Yusuff, Synthesis and characterisation of new transition metal complexes of Schiff bases derived from 3-hydroxyquinoxaline-2-carboxaldehyde and application of some of these complexes as hydrogenation and oxidation catalysts [Ph.D. thesis], Cochin University, 2009.

[35] M. A. Neelakantan, M. Esakkiammal, S. S. Mariappan, J. Dharmaraja, and T. Jeyakumar, "Synthesis, characterization and biocidal activities of some schiff base metal complexes," Indian Journal of Pharmaceutical Sciences, vol. 72, no. 2, pp. 216-222, 2010.

[36] S. Malik, G. Suparna, J. Bharti, S. Archana, and M. Bhattacharya, "Synthesis, characterization, and biological evaluation of some 3d-metal complexes of schiff Base derived from xipamide drug," International Journal of Inorganic Chemistry, vol. 2013, Article ID 549805, 6 pages, 2013.

[37] Z. H. Chohan, A. Munawar, and C. T. Supuran, "Transition metal ion complexes of Schiff-bases. Synthesis, characterization and antibacterial properties," Metal-Based Drugs, vol. 8, no. 3, pp. 137-143, 2001.

[38] R. B. Sumathi and M. B. Halli, "Metal (II) complexes derived from naphthofuran-2-carbohydrazide and diacetylmonoxime Schiff base: synthesis, spectroscopic, electrochemical, and biological investigation," Bioinorganic Chemistry and Applications, vol. 2014, Article ID 942162, 11 pages, 2014.

[39] O. B. Ibrahim, M. A. Mohamed, and M. S. Refat, "Nano sized schiff base complexes with $\mathrm{Mn}$ (II), $\mathrm{Co}(\mathrm{II}), \mathrm{Cu}(\mathrm{II}), \mathrm{Ni}(\mathrm{II})$ and $\mathrm{Zn}$ (II) metals: synthesis, spectroscopic and medicinal studies," Canadian Chemical Transactions, vol. 2, no. 2, pp. 108-121, 2014. 
[40] D. Suryarao and M. C. Ganorkar, "Potential fungitoxicity of some transition-metal chelates derived from dehydroacetic acid on Rhizoctonia-Solani," National Academy Science Letters, vol. 1, p. 402, 1978.

[41] D. Suryarao and M. C. Ganorkar, "Synthesis and physiologicalactivity of new schiff bases of dehydroacetic acid and their metal chelates," Current Science, vol. 49, p. 511, 1980.

[42] D. Suryarao and M. C. Ganorkar, "Synthesis and biological studies of some metal complexes of benzaldehyde salicyloylhydrazene," Journal of the Indian Chemical Society, vol. 58, p. 217, 1981.

[43] W. A. Sexton, Chemical Constitution and Biological Activity, E. \& F. N. Span, London, UK, 1963.

[44] D. Reddick and E. Wallace, "On a laboratory method of determining the fungicidal value of a spray mixture on solution," Science, vol. 31, p. 798, 1910.

[45] S. E. A. Mc Callan, "Studies on fungicides II. Testing protective fungicides in the laboratory," Cornell University Agricultural Experimental Station Manual, vol. 128, p. 14, 1930.

[46] Committee on Standardization of Fungicidal Test, The American Phytopathological Society, "The slide germination method for evaluating protectant fungicides," Phytopathology, vol. 33, pp. 627-632, 1943.

[47] Committee on Standardization of Fungicidal Test and The American Phytopathological Society, "The glass slide germination test by the test tube dilution method is adapted from a produce," Phytopathology, vol. 33, pp. 354-356, 1947.

[48] G. R. Mandels and R. T. Darby, "A rapid cell volume assay for fungitoxicity using fungus spores," Journal of Bacteriology, vol. 65, no. 1, pp. 16-26, 1953.

[49] H. H. Thornberry, "A paper-disc plate method for quantitative evaluation of funcgicides and bactericides," Phytopathology, vol. 40, pp. 419-420, 1950.

[50] E. G. Sharvelle, The Nature and Uses of Modern Fungicides, Burgess Publishing Company, St. Paul, Minn, USA, 1960.

[51] E. G. Sharvelle and E. N. Pellertier, "Modified paper-disc method for laboratory fungicidal bioassay," Phytopathology, vol. 46, p. 26, 1956.

[52] T. Mangamamba, [Ph. D. thesis], Osmania University, Hyderabad, India, 1982.

[53] V. Agnihotrudu, Rallis India, Fertilizers and Pesticides Division, P. B. No 168, Bangalore, India, pp. 69-71, 1973.

[54] S. H. Ou, Rice-diseases [Ph.D. thesis], IRRI, Laguna, Phillippines, 1979.

[55] R. S. Singh, Plant diseases, G. B. Panta University of Agriculture and Technology, Nainital, India, 1980.

[56] W. C. Vincent, Physiology of Fungi [Ph.D. thesis], Wesleyan University, Middletown, Conn, USA, 1979.

[57] B. S. Furniss, A. J. Hannaford, V. Rogers, P. W. G. Smith, and A. R. Tatchell, Eds., Vogel's Text Book of Practical Organic Chemistry, ELBS, London, UK, 1978.

[58] R. Stolle, "As per procedure benzol chloride and anhydrous hydrazine were mixed to obtain the desired benzohydrazine crystals," Journal für Praktische Chemie, vol. 69, p. 145, 1904.

[59] R. Hisada, H. Minato, and M. Kobayashi, "Aroyl arenesulfonyl peroxides IV. The mechanism of carboxy inversion of benzol p-toluenesulfonyl peroxide," Bulletin of the Chemical Society of Japan, vol. 45, no. 9, pp. 2816-2814, 1972.

[60] M. Ito and K. Yatugaku, Chemical Abstracts, vol. 34, p. 410, 1962.
[61] M. Dexter and B. Manor, "Polyolefin compositions stabilized against detertoration and copper 'wires coated with said compositions," N.Y., assignor to Geigy Chemical Corporation, Greenburgh, N.Y., a corporation of Delaware. Filed 1962, No. 176,451; US patent office, Patented 3,110,696, 1963.

[62] A. I. Vogel, A Text Book of Quantitative Organic Analysis, Longman, London, UK, 1976.

[63] D. R. Gupta and R. S. Gupta, Indian Chemical Society, vol. 42, 421, 1965.

[64] B. S. Furniss, A. J. Hannaford, V. Rogers, P. W. G. Smith, and A. R. Tatchell, Eds., Vogel's Text Books of Practical Inorganic Chemistry, ELBS, London, UK, 1978.

[65] B. Pradhan and D. V. R. Rao, Journal of the IndianChemical Society, vol. 57, p. 136, 1977.

[66] N. Saha and B. Deepak, Journal of Indian Chemical Society, vol. 58, p. 13, 1981.

[67] P. Rây, "Complex compounds of biguanides and guanylureas with metallic elements," Chemical Reviews, vol. 61, no. 4, pp. 313-359, 1961.

[68] U. V. Zelentsov, "Magnetic properties of oxovanadium(iv) complexes," Russian Journal of Inorganic Chemistry, vol. 7, p. 670, 1962.

[69] C. C. Lee, A. Shyamal, and L. J. Theriot, "Oxovanadium(IV) complexes with tridentate ONS donor ligands," Inorganic Chemistry, vol. 10, no. 8, pp. 1669-1673, 1971.

[70] S. N. Poddar, K. Day, J. Haldar, and S. C. Nathsarkar, "Magnetic properties of oxovanadium(IV) complexes of substituted $\mathrm{N}$ (hydroxyalkyl) salicylideneimines," Journal of the Indian Chemical Society, vol. 47, p. 743, 1970.

[71] Y. Kuge and S. Yamada, "Schiff base oxovanadium(IV) complexes with subnormal magnetic moments," Bulletin of the Chemical Society of Japan, vol. 43, no. 12, p. 3972, 1970.

[72] F. A. Cotton and G. Wilkinson, Advanced Inorganic Chemistry, Wiley-Eastern, New Delhi, India, 3rd edition, 1976.

[73] A. B. P. Lever, Inorganic Electronic Spectroscopy, Elsevier, Amsterdam, The Netherlands, 1968.

[74] R. S. Drago, Physical Methods in Inorganic Chemistry, vol. 168, Reinhold, 1965.

[75] G. N. Figgis and J. Lewis, Progress in Inorganic Chemistry, vol. 6, International Scientific Publications, New York, NY, USA, 1964.

[76] A. Earnshaw and J. Lewis, "Magnetic properties of some binuclear complexes," Journal of the Chemical Society, pp. 396404, 1961.

[77] R. H. Holm, G. W. Everett Jr., and A. Chakravorty, "Metal complexes of Schiff bases and $\beta$-ketoamines," Progress in Inorganic Chemistry, vol. 7, pp. 83-214, 1966.

[78] K. L. Madhok and K. P. Srivatsav, "Synthesis and characterization of hexa, hepta and octa-coordinated $\mathrm{Nb}(\mathrm{V})$ complexes of $\mathrm{N}, \mathrm{N}^{\prime}$-(dsubstituted)-formamidino- $\mathrm{N}^{\prime}$-(substituted) carbamides and thiocarbamides," Proceedings of the Indian Academy of Sciences: Chemical Sciences, vol. 92, no. 6, pp. 605612, 1983.

[79] W. M. Reiff, A. W. Baker Jr., and N. E. Erickger, "Binuclear, oxygen-bridged complexes of iron(III). New iron(III)-2,2 $2^{\prime} 2^{\prime \prime}$ terpyridine complexes," Journal of the American Chemical Society, vol. 90, no. 18, pp. 4794-4800, 1968.

[80] R. H. Holm and J. O'Connor, "The stereochemistry of bischelate metal(II) complexes," Progress in Inorganic Chemistry, vol. 14, pp. 241-401, 1971.

[81] B. N. Figgis, Introducion to Ligand Field Theory, chapter 10, Interscience Publishers, New York, NY, USA, 1966. 
[82] G. N. Figgis and J. Lewis, in Progress in Inorganic Chemistry, vol. 6, International Scientific Publications, New York, NY, USA, 1964.

[83] K. D. Buttler, K. S. Murray, and B. O. West, "Magnetic properties of some tridentate Schiff base manganese (II) complexes," Australian Journal of Chemistry, vol. 24, no. 11, pp. 2249-2256, 1971.

[84] C. L. Perry and J. M. Weber, " Complexes of pyrrole-derivative ligands-III: some first transition series metal complexes of bidentate ligands," Journal of Inorganic and Nuclear Chemistry, vol. 33, pp. 1031-1039, 1971.

[85] J. P. Jesson, S. Trofimenko, and D. R. Eaton, "Spectra and structure of some transition metal poly(1-pyrazolyl) borates," Journal of the American Chemical Society, vol. 89, no. 13, pp. 3148-3158, 1967.

[86] R. H. Holm, "Studies on Ni(II) complexes. I. Spectra of tricyclic Schiff base complexes of $\mathrm{Ni}(\mathrm{II})$ and $\mathrm{Cu}(\mathrm{II})$," Journal of the American Chemical Society, vol. 82, no. 21, pp. 5632-5636, 1960.

[87] W. K. Musker and M. S. Hussain, "Medium-ring complexes. III. Comparison of planar and pyramidal copper(II) and planar nickel(II) complexes containing seven- and eight-memberedring diamines," Inorganic Chemistry, vol. 8, supplement 3, pp. 528-536, 1969.

[88] A. Shyamal and K. S. Kale, Indian Journal of Chemistry A, vol. 16, pp. 46-48, 1978.

[89] S. G. Kulkarni, [Ph.D. thesis], Department of Chemistry, Maratwada University, Aurangabad, India.

[90] A. Earnshaw, Introduction to Magneto Chemistry, Academic Press, New York, NY, USA, 1969.

[91] K. Nakamoto, IR Spectra of Inorganic and Coordination Compounds, Wiley-Interscience, New York, NY ,USA, 1972.

[92] K. Ueno and A. E. Martell, "Infrared study of metal chelates of bisacetylacetoneethylenediimine and related compounds," The Journal of Physical Chemistry, vol. 59, no. 10, pp. 998-1004, 1955.

[93] K. Ueno and A. E. Martell, "Infrared studies on synthetic oxygen carriers," The Journal of Physical Chemistry, vol. 60, no. 9, pp. 1270-1275, 1956.

[94] J. Selbin, “Oxovanadium(IV) complexes," Coordination Chemistry Reviews, vol. 1, no. 3, pp. 293-314, 1966.

[95] G. W. Watt and J. W. Dowes, "Copper(0) phthalocyanine," Journal of Inorganic and Nuclear Chemistry, vol. 14, no. 1-2, pp. 32-34, 1960.

[96] M. R. Truter and K. W. Rutherford, "333. The cystal structure of tetrakisthioacetamidecopper(I) chloride," Journal of the Chemical Society, pp. 1748-1756, 1962.

[97] F. A. Cotton and G. Wilkinson, Advanced Inorganic Chemistry, Wiley-Eastern, New York, NY, USA, 3rd edition, 1972.

[98] W. H. T. Davison and P. E. Christie, "Infrared spectra of semicarbazones," Journal of the Chemical Society, pp. 3389-3391, 1955.

[99] M. Kubo, M. Kuroda, M. Krishita, and Y. Muto, “ The structure of three-coordinated copper(II) complexes and the infrared $\mathrm{C}=\mathrm{O}$ stretching vibration," Australian Journal of Chemistry, vol. 16, no. 1, pp. 7-13, 1963.

[100] K. Nakamoto, Infra Red Spectra of Inorganic and Coordination Compounds, Wiley-Interscience, New York, NY, USA, 1961.

[101] I. Suzuki, "Infrared spectra and normal vibrations of thioamides. I. Thioformamide," Bulletin of the Chemical Society of Japan, vol. 35, no. 8, pp. 1286-1293, 1962.

[102] B. Pradhan and D. V. R. Rao, Journal of the Indian Chemical Society, vol. 48, p. 136, 1971.
[103] V. K. Mahesh and R. S. Gupta, Indian Journal of Chemistry, vol. 12, no. 6, pp. 570-572, 1974.

[104] V. V. Rana, S. K. Sahani, M. P. Swami, P. C. Jain, and A. K. Srivathsava, "Thiosemicarbazones as ligands-III. Oxovanadyl (IV) complexes of substituted-4-benzamidothiosemicarbazones," Journal of Inorganic and Nuclear Chemistry, vol. 38, no. 1, pp. 176-180, 1976.

[105] R. Pappalardo, "Ligand field theory and the absorption spectra of $\mathrm{MnCl}_{2}$ and $\mathrm{MnBr}_{2}$," The Journal of Chemical Physics, vol. 31, article 1050, 1959.

[106] S. Y. Shaw and E. P. Dudek, "Bidentate bis(N-substituted 2acetiminodimedonato)nickel(II) complexes," Inorganic Chemistry, vol. 8, no. 6, pp. 1360-1366, 1969.

[107] D. Sutton, Electronic Spectra of Transition Metal Complexes, McGraw-Hill, New York, NY, USA, 1968, p. 148.

[108] D. Satyanarayana and V. Mohapatra, Journal of the Indian Chemical Society, vol. 13, pp. 186-188, 1975.

[109] L. Sacconi and M. Ciampolini, "45. Pseudo-tetrahedral structure of some $\alpha$-branched copper(II) chelates with Schiff bases," Journal of the Chemical Society (Resumed), pp. 276-280, 1964.

[110] A. K. Muzundar and P. K. Bhattacharya, "Effect of mono-ligands on Schiff base complexes-II. Copper(II) complexes," Journal of Inorganic and Nuclear Chemistry, vol. 30, no. 4, pp. 1116-1119, 1968.

[111] M. Sheela, "The ultra-violet and visible spectra of some transition metal chelates with $N, N^{\prime}$-bis-(o-hydroxybenzylidene)ethylenediamine and $N, N^{\prime}$-bis-( $o$-hydroxybenzylidene)- $o$ phenylenediamine and related compounds," Spectrochimica Acta, vol. 19, no. 1, pp. 255-270, 1963. 

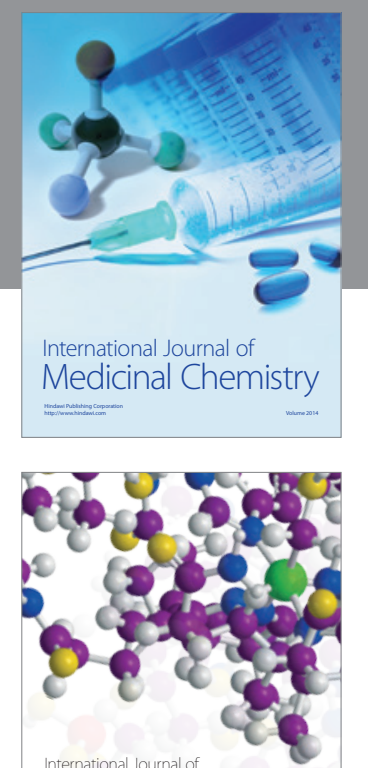

\section{Carbohydrate} Chemistry

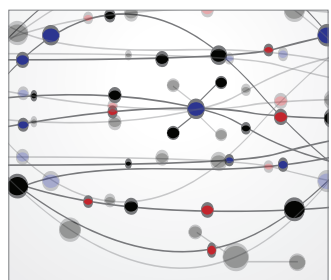

The Scientific World Journal
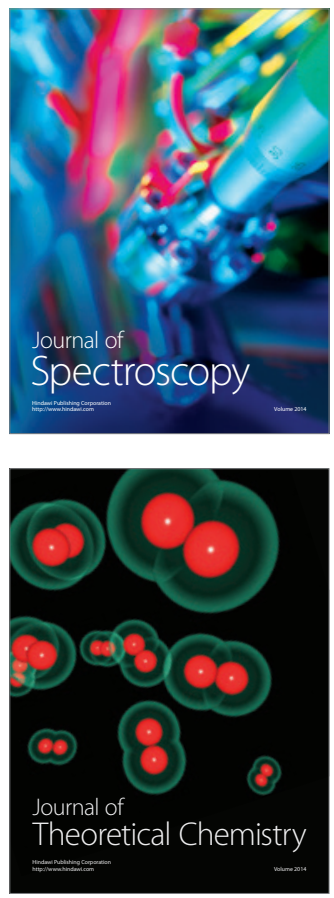
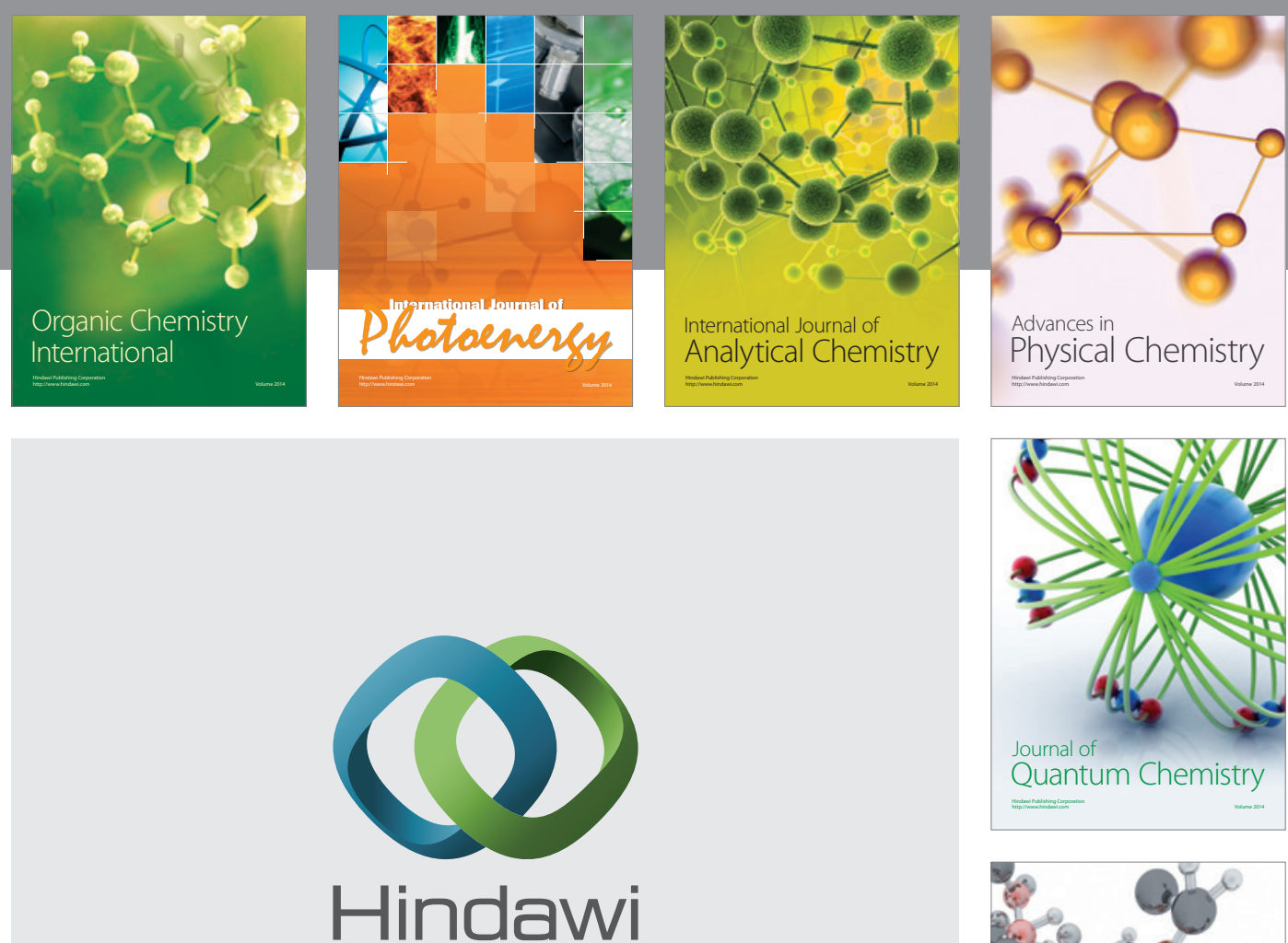

Submit your manuscripts at

http://www.hindawi.com

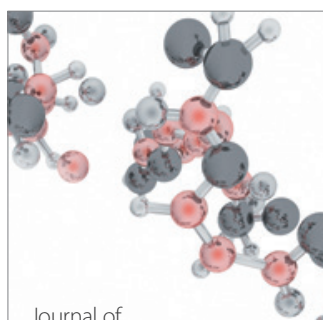

Analytical Methods

in Chemistry

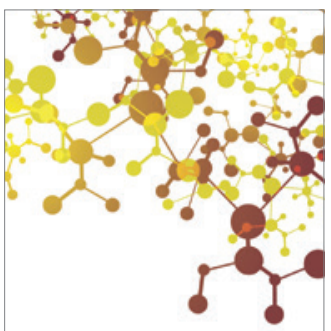

Journal of

Applied Chemistry

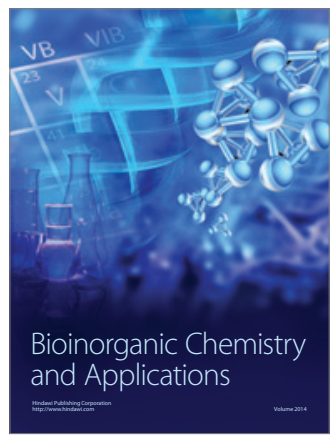

Inorganic Chemistry
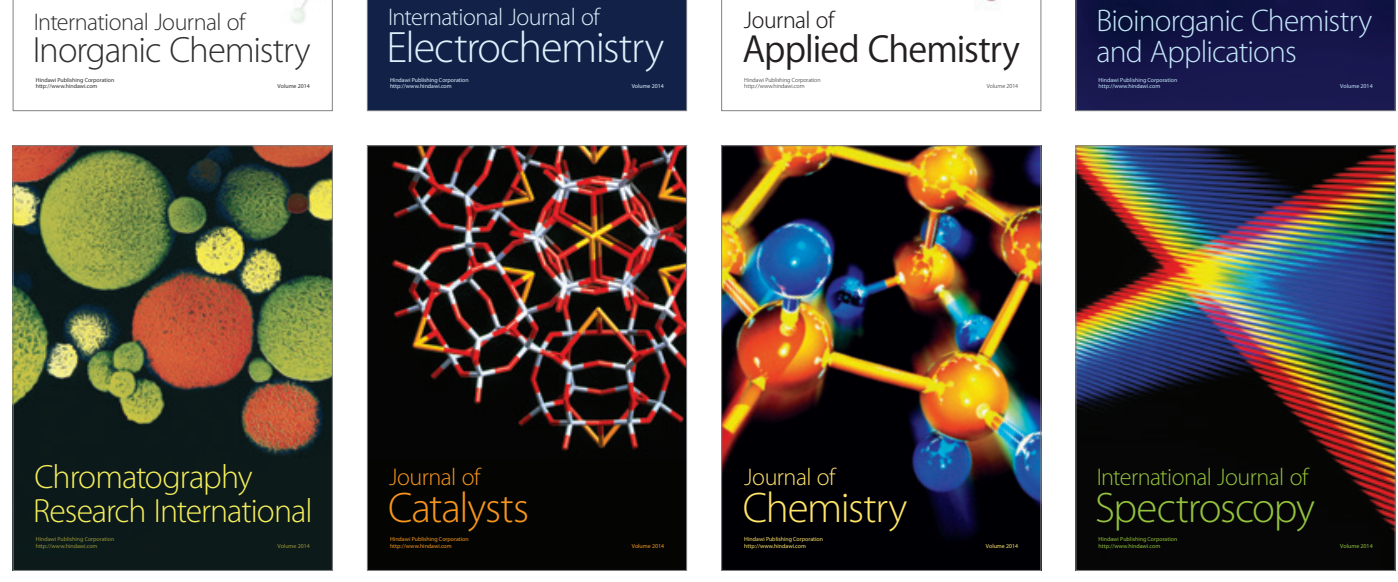